EstAg 31 (1996) 405-447

\title{
Retos Ecuménicos que pesan sobre la Iglesia Católico-Romana
}

\author{
(REFLEXIONES A PROPOSITO DE LA UT UNUM SINT)
}

Juan Pablo II tiene una querencia congénita a fijarse en fechas cristianamente significativas, aprovechándolas para lanzar mensajes y proponer metas a las creyentes y a los creyentes. Todavía quedan ecos de tal conducta con motivo del año 1992, año en que se celebraba el 5 centenario del descubrimiento y la evangelización de la América hispana. Con motivo de esa fecha Juan Pablo II lanzó la consigna de la nueva evangelización. Expresión que pronunció por primera vez en una visita a algunos países de América hispana y que, luego, vista la situación del cristianismo en la vieja Europa, la extendió a este Continente. La expresión no tenía en un principio un rostro muy perfilado, hasta el extremo de que algunos, que se dedicaron a escribir sobre ella, la encontraron un tanto ambigua. Lo cierto es que, con el tiempo, corrió como la pólvora y, sin saber muy bien qué se escondía tras esas tres palabras, ha servido para producir bastante literatura religiosa. Otra cosa es saber, si todo ese revuelo producido ha cuajado en algo positivo. Algo que no puede ser otra cosa que la obligación que tiene la iglesia católico-romana de poner el reloj de su mensaje en hora y no tanto de emprender empresas, como una posible vuelta a un cierto régimen de cristiandad, que tienen de entrada todos los datos a favor de un fracaso. Textos papales, muy significativos, por cierto, parecen apuntar desgraciadamente en esta dirección, que, como ya indiqué, está abocada al fracaso.

En el horizonte de inquietud dibujado, no podía pasar desapercibido para Juan Pablo II el simbólico año 2000. Una fecha a la que él viene haciendo referencia desde bastantes años atrás. Esta fecha tiene para el papa actual un cierto carácter mágico. Es, como se sabe, la fecha no exacta, cosa que no tiene mayor importancia, del nacimiento de Cristo. El hecho colma las más urgentes aspiraciones de Juan Pablo II. Aparte de referencias constantes al mismo, Juan Pablo II ha escrito dos cartas encíclicas. Una, con el título: Ter- 
tio millennio adveniente. Otra, con el título: Ut unum sint. La primera tiene como telón de fondo y tema principal la promulgación de un gran Jubileo. Jubileo que deberá ir precedido de tres años de preparación. Son 1997, 1998 y 1999. 1997 estará dedicado al Espíritu Santo. 1998, al Hijo de Dios, hecho hombre. 1999, al Padre, como fuente y origen tanto del misterio trinitario, como del misterio de la salvación. La segunda tiene como tema central la unidad entre las iglesias cristianas.

La carta encíclica Ut unum sint fue saludada por la prensa adicta a los mensajes de Roma como un paso gigante en el camino de la unidad. Entusiasmado por todo lo que tiene como referencia el tema de la unidad de los cristianos, regusté con gozo sabroso lo que se decía de la carta encíclica. ¡Qué mejor noticia para el ecumenismo podría recibirse que un personaje tan único como el papa apostara de forma positiva por la unidad de todos los cristianos! He dicho de forma positiva, para poner de relieve que aquí sobran sentimentalismos y es preciso ofertar alternativas teológicamente válidas.

Espoleado por el ansia de conocer qué es lo que había de verdad en las apreciaciones hechas por la prensa, decidí leer despacio y serenamente la carta encíclica. Llegué a la conclusión totalmente contraria. El papa no da un solo paso adelante. La carta encíclica se reduce a citar casi en su totalidad el decreto del concilio Vaticano II sobre la unidad de los cristianos. Decreto que, como se sabe, se cita con sus dos palabras primeras, que son Unitatis redintegratio. En siglas: $U R$. A ello añade un alto número de encuentros que ha mantenido con distintos corifeos de iglesias cristianas.

Todos sabemos que el decreto Unitatis redintegratio $(=U R)$ es el fruto primerizo de una iglesia, la católico-romana, que se asomaba por primera vez con mirada un tanto renovada al balcón del ecumenismo, movimiento cristiano que se interesa por alcanzar la unión de todas las iglesias. Movimiento, por lo demás, nacido fuera y al margen de la iglesia católico-romana. Juan XXIII, con antenas sumamente finas para captar el significado de los signos de los tiempos, acoge con simpatía el movimiento ecuménico y nombra un organismo, el Secretariado para la unión de los cristianos, que tiene como razón de ser trabajar en la línea que hizo nacer el movimiento ecuménico. Este secretariado ha cambiado de nombre y hoy se llama Consejo pontificio para la unión de los cristianos.

Es muy importante fijar la atención en las palabras fruto primerizo. La expresión sólo puede entenderse justamente, si se tiene en cuenta el dato histórico. En efecto, la iglesia católico-romana había ejercido siempre el estilo de ecumenismo llamado unionista. Su eje de contenido es éste: todas las demás iglesias o comunidades cristianas, que se habían separado de la iglesia católico-romana, habían abandonado la casa paterna y, como buenos hijos 
pródigos, no quedaba otra alternativa que volver a la casa. "La unionista es la visión tradicional y oficial hasta el concilio Vaticano II. Los católicos, muchas veces de manera generosa, trabajan para que los 'disidentes' -'cismáticos' o 'herejes'- vuelvan a la casa paterna, la iglesia católica, que sus antepasados abandonaron. Para los 'hermanos separados' sólo queda 'el camino del retorno'. El apostolado unionístico -viendo el oro que se ha separado del filón aurífero- puede facilitar dicho retorno 'al único redil, bajo un solo Pastor'. En esta perspectiva escriben, cuando tratan del restablecimiento de la unidad, León XIII, en la encíclica Praeclara gratulationis (1894) y Satis cognitum (1896), Pío XI, en Mortalium Animos (1928), y también Pío XII en la encíclica Mystici Corporis (1943). En este mismo sentido escribe el Padre Charles Boyer al presentar, en 1946, la revista Unitas, donde contrapone el deseo de los católicos por la unidad con la nostalgia de los que no lo son." 1 .

El texto citado retrata estupendamente ese estilo de ecumenismo que se ha llamado unionista. Es, como fácilmente se puede detectar, una clara muestra de cómo se entiende a sí misma la iglesia que lo practica. Dicha iglesia, en el caso la iglesia católico-romana, tiene la conciencia de ser la verdadera iglesia de Cristo. Conciencia a la que no puede renunciar, si quiere ser fiel a la voluntad del Señor. Así las cosas el único ecumenismo practicable y aceptable es el unionista. Para las otras iglesias o comunidades no queda otra alternativa que la vuelta a la verdadera iglesia de Cristo. No extraña, por tanto, que este estilo de ecumenismo es el que se haya practicado en la iglesia católico-romana hasta el concilio Vaticano II.

Si comparamos ahora este estilo de ecumenismo con el ecumenismo propiamente tal, es decir el movimiento que nació para buscar la unión de los cristianos, se notarán diferencias muy acusadas. Ambos persiguen el mismo fin: la unión de los cristianos. Sin embargo, su mismo meollo es absolutamente diverso. Para el ecumenismo como movimiento que se interesa por la unión de los cristianos, todas las iglesias o comunidades cristianas se colocan en un mismo pie de igualdad. Ninguna es más que otra, si vale la expresión. El diálogo es el instrumento a usar, cuando se trata de buscar caminos de convergencia. Aquí es imposible el uso del retorno a la casa de quienes se han ido de ella. Todas las iglesias, unas más, otras menos, deben someterse al juicio de Dios, purificándose de cosas que no responden al plan divino para la iglesia. Así nació y se configuró el movimiento ecuménico. "El acer-

1. VERCRUYSSE, J. E., Introducción a la Teología Ecuménica. Verbo Divino, Estella (Navarra), 1993, pp. 72. 
camiento ‘ecuménico' (póngase aquí el movimiento ecuménico), en cambio, fue descrito por el Padre Yves Marie J. Congar, en 1937, en Chrétiens désunis. Principes d'un 'oecumenisme' catholique, la primera reflexión amplia eclesiológica católica acerca del movimiento ecuménico moderno. En esta perspectiva, la unión no es fruto del retorno a un redil, sino más bien el resultado de un camino común de conversión y reforma hacia una nueva integración, cuya realización en el tiempo sólo Dios conoce, de todos los valores auténticamente cristianos y de todas las iglesias en la catolicidad, la cual trasciende a todas y cada una de las existentes" ${ }^{2}$.

El concilio Vaticano II se encuentra con estos dos estilos de ecumenismo: el oficialmente usado por la iglesia católico-romana y el nacido fuera de sus fronteras, acogido ya y reflexionado por teólogos católicos. Ejemplo: el P. Congar, que se acaba de recordar. A la hora de elaborar su decreto sobre el ecumenismo, el concilio Vaticano II se aparta del modelo unionista y entra por el camino, sin más, del ecumenismo. La opción, no obstante, acusa implicaciones eclesiológicas claramente adoptadas por el concilio Vaticano II. Implicaciones que, de algún modo, recortan y oscurecen la opción. En efecto, el concilio Vaticano II afirma que "esta iglesia, (se refiere a la iglesia de Cristo), constituida y ordenada en este mundo, permanece (subsistit) en la iglesia católica, gobernada por el sucesor de Pedro y por los obispos en comunión con él, aunque puedan encontrarse fuera de ella muchos elementos de santificación y de verdad que, como dones propios de la iglesia de Cristo, inducen hacia la unidad católica" ${ }^{3}$. En el decreto sobre el ecumenismo afirma: "Jesucristo quiere que se desarrolle por medio de la fiel predicación del Evangelio y la administración de los sacramentos y por el gobierno en el amor, efectuado todo ello por los apóstoles y sus sucesores, es decir, por los obispos con su cabeza, el sucesor de Pedro, obrando el Espíritu Santo; y realiza su comunión en la unidad: en la profesión de una sola fe, en la común celebración del culto divino y en la concordia fraterna de la familia de Dios" 4.

El concilio Vaticano II rehúye usar el verbo ser a la hora de hablar de la relación entre la iglesia de Cristo y la iglesia católico-romana. No dice ya, como se venía diciendo, que la iglesia católico-romana es la iglesia de Cristo. Así lo había dicho Pío XII en la encíclica Mystici corporis. "Ahora bien, para definir y describir esta verdadera iglesia de Cristo -que es la iglesia santa,

2. Ib., pp. 73.

3. Constitución sobre la iglesia $=\mathrm{LG} 8 \mathrm{c}$.

4. UR $2 \mathrm{~d}$. 
católica, apostólica, Romana- nada hay más noble, nada más excelente, nada más divino que aquella frase con que se llama 'el cuerpo místico de Cristo', expresión que dimana y brota de lo que en las Sagradas Escrituras y en escritos de los Santos Padres frecuentemente se enseña" ${ }^{5}$. El concilio Vaticano II matiza más su mensaje, hasta el extremo de dejar espacio, pequeño seguramente, para no hacer una equiparación total entre la iglesia de Cristo y la iglesia católico-romana. Con todo, no hay que dudar que el concilio Vaticano II tiene la convicción de que la iglesia católico-romana es la representación más acabada de la iglesia de Cristo. Y lo es, entre otras cosas, principalmente por estar gobernada por los obispos, sucesores de los apóstoles, a quienes preside, como cabeza, el papa, sucesor de Pedro. Las demás iglesias, llámense así o llámense comunidades cristianas, carecen de ese signo o de esa realidad que el concilio Vaticano II presenta como algo querido por Cristo.

De todo esto se deduce una conclusión intocable: según el concilio Vaticano II la unión entre las iglesias sólo es factible bajo el presupuesto de aceptar la estructura episcopal tal y como se halla en la iglesia católico-romana. Si nos atenemos a la enseñanza del concilio Vaticano II no se puede pasar de aquí. Las demás iglesias se ven bajo este prisma y se valora su fuerza eclesial sólo desde esta perspectiva. Con lo que se rompe la iguadad a la hora de llevar a cabo un diálogo que pueda alcanzar el suficiente consenso para conseguir la unidad. Solapadamente el concilio Vaticano II sigue ofreciendo, parece que no hay otra alternativa, el modelo ecuménico del retorno. Eso sí, lo hace con un lenguaje muy delicado, reconociendo los signos de salvación que hay en las otras iglesias o comunidades. Pero lo hace también como consecuencia de una concepción eclesiológica secular de la que el concilio Vaticano II no acabó de desprenderse.

Aquí sitúo yo la expresión de documento primerizo. $\mathrm{Y}$, por lo mismo, documento de partida y no de llegada. No sé si en el tiempo del concilio Vaticano II se conocía, por ejemplo, todo lo que hoy se conoce acerca del nacimiento, desarrollo y formas del Ministerio. Lo que sí sé es que hoy en día los estudios sobre el tema dejan bien a las claras las lagunas conciliares al respecto. Por ello, la oferta ecuménica del concilio Vaticano II, al menos desde el punto de vista del Ministerio, es una oferta corta. En su momento, tal vez no había otra posibilidad. No hay que olvidar que el concilio Vaticano II hace su primer escarceo en el tema. Y, en verdad, es preciso reconocer que en el decreto sobre el ecumenismo alienta otro espíritu del que venía

5. Mystici corporis $=\mathrm{MC} 9 \mathrm{~b}$, 
moviendo los hilos ecumenistas en la iglesia católico-romana. Mas ello no impide reconocer sus limitaciones. Por lo que extraña que una carta encíclica como la de Juan Pablo II, escrita casi treinta años más tarde, se reduzca a repetir casi literalmente lo que dijo el concilio Vaticano II. Creo que en 1995, año en el que Juan Pablo II escribe su carta encíclica, se conocen cosas que el papa no acusa en un tema que, como el Ministerio, en general, y el suyo, en particular, impone en la iglesia católico-romana y a la iglesia católicoromana cambios importantes de contenido. Por eso, me permito afirmar que la carta encíclica de Juan Pablo II no es un paso adelante en el ecumenismo. A lo más, es quedarse en donde se situó el concilio Vaticano II.

De ahí el título: Retos ecuménicos que pesan sobre la iglesia católicoromana. Y de ahí también el subtítulo: Reflexiones con motivo de la 'Ut unum sint'. Mi trabajo no va a tener como tema la carta encíclica de Juan Pablo II. Simplemente aprovecho su aparición para ofrecer un tema de importancia capital en el campo del ecumenismo. Es el tema del Ministerio. Lo pongo con mayúscula, para diferenciarlo del ministerio de la iglesia universal, en cuyo terreno hay que situarlo, si se quiere tener una visión correcta del mismo. Todo ello en la línea marcada por este significativo texto: "La iglesia tiene por consiguiente la misión de proclamar el evangelio a todos, creyentes y no creyentes. Esta misión o servicio de toda la iglesia es llamada 'ministerio' (diakonía). En el curso de esta declaración empleamos el término ministerio (con minúscula, con o sin artículo) en este sentido. El ministerio de la iglesia entendido de esta manera se distinguirá del (o un) Ministerio, una forma particular de servicio - un orden específico, función o carisma- que se encuentra dentro y en benificio de la iglesia de Cristo en su misión hacia el mundo. El término Ministro empleado en este documento se refiere a la persona a quien ha sido confiado este Ministerio. Estamos convencidos de que el Ministerio especial no puede ser discutido aparte, sino en el contexto de todo el pueblo de Dios" ${ }^{6}$.

Quiero también poner de manifiesto mis más delicadas intenciones. El título es ciertamente un tanto provocativo. Se interpretaría mal, si se quisiera ver en él un afán de dar lecciones a alguien, en este caso, a la iglesia católico-romana. Como si intentara marcar el camino que debe seguir. Mi reflexión nace sólo y exclusivamente del amor a Cristo y a su iglesia. Una iglesia dividida, alejada, desde esta perspectiva, de la voluntad expresa del Señor. La división, aparte la responsabilidad que pueda haber o no en ella, nos

6. GRUPO TEOLÓGICO LUTERANO-CATÓLICO DE ESTADOS UNIDOS, Ministerio y eucaristía. Seminarios 57-58, vol. 21, julio-diciembre, 1975, $\mathrm{n}^{\circ} 9$, pp. 471. 
debe doler a todos los que llevamos el nombre de cristianos. Por ello, todos debemos, en la medida de nuestras posibilidades, poner nuestro granito de arena, a fin de que el sol de la unidad brille sobre el firmamento eclesial lo antes posible. Hay cosas que todos podemos y debemos hacer. Orar, vivir una vida de testimonio cristiano, ver a todos los que llevan el nombre de cristianos como hermanos sin aditamentos de ninguna clase, respetar lo que en otras iglesias se hace y se vive como respuesta al evangelio. Hay otras cosas que no todos pueden hacer. Son las cosas técnicas, las cosas que encierran problemas teológicos. Intentar esta labor, desde la sencillez, desde la humildad, desde el amor intenso a la iglesia y al Señor de la misma es siempre laudable. Y ello es lo que voy a hacer en este artículo. Quiero hacerlo desde los datos de la investigación, marginando todo lo que pueda tener cariz dogmático injustificado. Por lo que buscaré la mayor objetividad posible, aunque ello conlleve cuestionar cosas que parecen intocables. Comienzo ya la exposición del tema tras este prolongado discurso que bien puede considerarse como una introducción.

\section{PRIMER RETO: EN OBSEQUIO A TODAS LAS IGLESIAS RESTAN- TES, EN PARTICULAR A LAS IGLESIAS ORTODOXAS, "RE-VISAR" SU FORMULACION TEOLÓGICA Y SU PRAXIS DEL PAPADO}

Aparece en el encabezamiento la palabra re-visar. La escribo con temor y temblor. Sé que levantará ampollas a conciencias inclinadas a magnificar el magisterio eclesiástico. Máxime, cuando se trata, como es el caso, de un concilio calificado de "ecuménico", como es el concilio Vaticano I. A pesar de todo el respeto que me merecen tales personas y a pesar de todo el respeto que me merece la doctrina de un concilio, creo que hay motivos teológicos, es decir no sólo coyunturales, para llevar a cabo esa labor. Inicio el trabajo escalonadamente.

Todos sabemos que, a nivel universal, es decir incluyendo todas las iglesias, se reconocen tan sólo como "ecuménicos" los siete primeros concilios. Todos ellos celebrados antes de la separación de la iglesia ortodoxa acaecida en el año 1054. Desde esta triste fecha tan sólo dos concilios, el II de Lyón y el de Florencia, han contado con la presencia de los griegos. Presencia que no alcanzó más que resultados pasajeros por lo que mira a la reunificación de ambas iglesias. La separación entre ambas iglesias sigue presente. A ella hay que añadir la acontecida en Occidente durante el siglo XVI. De ella nacieron las iglesias de la Reforma con una enorme variedad de las mismas. 
No hay que marginar en el tema a los vétero-católicos. Los viejos católicos, que esto es lo que significa la expresión vétero-católicos, son un número reducido, pero muy importante, que tienen su presencia principalmente en los Países Bajos, que ven en el obispo la figura ministerial más importante y que se oponen, de ahí su alejamiento de la iglesia católico-romana, a los pronunciamientos dogmáticos acerca del papa del concilio Vaticano I.

Todo ello conduce a distinguir entre concilio ecuménico y concilio general. El primero representa a toda la iglesia. El segundo, a una iglesia en concreto. Oigamos un texto al respecto: "Precisamente con ocasión del último de ellos, algunos prestigiosos historiadores e incluso representantes de la jerarquía tomaron distancias del carácter absolutamente vinculante de este catálogo (se está refiriendo al catálogo de concilios ecuménicos según la iglesia católico-romana), conscientes de las implicaciones eclesiológicas que esto suponía. Unos años más tarde, Pablo VI se referirá al segundo concilio de Lyón, celebrado en 1274 y que ocupa el decimocuarto en la citada lista 'ecuménica', como el 'sexto de los concilios generales celebrados en el mundo occidental'. Vale la pena recordar de paso que, como dentro de la fluctuante objetivación usada para los concilios, ya Nicolás de Cusa, en su obra De concordia catholica, elaborada en torno a los años treinta del siglo XVI, hacía notar que el hecho de haber desaparecido la distinción entre 'concilio ecuménico', es decir, universal, y 'concilio general', o sea, de una determinada región cristiana, era atribuible a la ruptura entre la iglesia 'romana' y las 'iglesias ortodoxas' de Oriente" 7 .

Louis Bouyer, protestante venido al catolicismo, autor nada sospechoso de avanzado, escribe sobre el tema unas bien ponderadas reflexiones. "La postura que hemos adoptado en este libro, y según la cual la iglesia católica y la iglesia ortodoxa jamás han dejado de constituir y de ser una iglesia, lleva consigo inevitablemente una cuestión, a saber: los concilios generales que se han reunido en Occidente desde el siglo XI, ¿pueden ser considerados como ecuménicos en el sentido pleno de la palabra? En efecto, la Edad Media latina que, en la práctica al menos, tenía sobre la unidad de la iglesia una postura correspondiente a la que nosotros acabamos de reemprender para intentar sacar todas sus consecuencias, nunca admitió estos concilios generales de Occidente sobre el plano de los siete concilios de la antigüedad. No se ha llegado a una postura distinta sino desde Belarmino y a su continuación. La cuestión fue dilucidada de una manera que se puede decir definitiva por Vittorio Peri, en su libro Concilii e Chiese, Roma, 1965.

7. ZAMBARBIERI, A., Los concilios del Vaticano. San Pablo, Madrid, 1995, pp. 15-16. 
No se sigue de ahí que las decisiones dogmáticas de los concilios generales posteriores a la separación no sean de una alta y subida autoridad. Nosotros lo hemos dicho ya, en efecto, que la iglesia admitió siempre que los concilios parciales, en algunos determinados casos, podían expresar de manera definitiva la mens ecclesiae. Este debe ser el caso, hasta cierto punto, de todos los concilios convocados por el papa y confirmados por él después de haber reunido una representación episcopal considerable.

No es menos verdadero que sus decisiones, aun cuando puedan ser consideradas como infalibles y, por consiguiente, irreformables, por el hecho de que han sido tomadas en ausencia de una porción considerable del episcopado, la cual habría representado una tradición teológica de los más venerables, sin embargo, pueden exigir complementos ulteriores que no se habrían necesitado en el caso de un concilio ecuménico en el sentido más antiguo y verdaderamente plenario de la palabra"11.

La distinción entre concilio ecuménico y concilio general, impuesta por la realidad cruda de los hechos, invita a mirar las enseñanzas conciliares últimas con ojos nuevos. Dejando a un lado el tema de la infalibilidad de tales asambleas, tema que no quedaría en principio descartado, es preciso reconocer que la distinción entre concilio ecuménico y concilio general abre, por un lado, una gran ventana y posibilita nuevos campos de visión y, por otro, dibuja un camino que puede conducir a metas un tanto diferentes de las que se han considerado alcanzadas. Por lo que respecta al concilio Vaticano I y a su formulación teológica del papado y de la infalibilidad del papa es posible decir que, de haber estado presentes las iglesias ordoxas y las iglesias surgidas de la Reforma, no se habría llegado a las conclusiones que se llegaron. No hay que olvidar que en el seno del mismo episcopado católico hubo una fuerte oposición a la declaración de la infalibilidad pontificia.

A lo que hay que añadir, y ello aparece con fuerza, si se estudian los entresijos del concilio Vaticano I, que este concilio se desarrolla con unos condicionamientos dignos de tenerse en cuenta. Su duración es escasa. No dura ni siquiera un año. Comienza el 8 de diciembre de 1869. Termina el 20 de octubre de 1870 . Termina de forma brusca. No tuvo, ni ha tenido, un cierre oficial. Los Padres tuvieron que huir a uña de caballo, en vista a la situación social de Roma. Este reducido espacio de tiempo se vio todavía agravado por pérdidas sustanciales de tiempo, dada la poca organización que existía. En un tono un tanto gracioso, pero expresando un profundo pesar, uno de los padres conciliares, en concreto el obispo de Málaga, monseñor Pérez Fernández, decía en una intervención: "Dos largos meses, casi tres,

8. BOUYER. L., La iglesia de Dios. Studium, Madrid, 1973, pp. 678. 
han pasado desde que se inició este concilio Vaticano. $\mathrm{Y}_{\text {¿a qué conclusión }}$ hemos llegado? A lo que los apóstoles le dijeron a su maestro: hemos estado trabajando toda la noche y no hemos cogido nada... ¡A Ah, tantas congregaciones, tan largas y amplias discusiones y no hemos aprobado ni un solo esquema, ni un capítulo, ni un canon... ¿Adónde vamos?... ¿Conseguirá su fin el concilio Vaticano?" 9.

Tampoco hay que olvidar el estado de ánimo de la iglesia católico-romana. Se trata de una iglesia asustada hasta cotas impensables. Una evidencia brutal le hace ver que ya no es la iglesia del pasado, poderosa, impositiva, forjadora de culturas. Una serie de acontecimientos se lo están diciendo a gritos. Políticamente, el papado, fortaleza casi inexpugnable de poder absoluto, ve cómo se le escapa tal prebenda. Se está consumando la pérdida de los territorios pontificios. Las tropas de Garibaldi, defensoras de la unificación de Italia, avanzan hacia Roma y lograrán su entrada en pleno desarrollo del concilio. Desde años atrás, sus orígenes hay que buscarlos en la última parte de la Edad Media, su plenitud en los postulados de la Revolución francesa, se ha ido construyendo un modelo de cultura que la iglesia no ve con buenos ojos. Ello hace tambalear el edificio eclesial en su pensamiento y en su actuación. La iglesia, en concreto sus instancias superiores, más en concreto el papa, reaccionan contra todo ese mundo que ven como presencia de los poderes satánicos de forma un tanto instintiva. Se impone cerrar filas alrededor del jefe. Nunca mejor que ahora la imagen de una iglesia vista como acies ordinata. Es decir, como un ejército preparado para la batalla. Es preciso echar mano de la obediencia más absoluta a todo lo que viene de arriba y magnificar, ¿divinizar?, la imagen del jefe. La iglesia arremete contra todo lo que viene de fuera, condenando todos los movimientos culturales que no entraban en sus esquemas medievales. Desde esta perspectiva, se explica el Syllabus, elenco de proposiciones reprobables. Entre las que se encuentra que el papa no puede congraciarse con la cultura moderna ${ }^{10}$.

Tenemos aquí una buena clave hermenéutica para poder encontrar justificación a la acuñación que el concilio Vaicano I hace del ministerio papal. En particular, el tema de la infalibilidad. Hay en todo ello una especie de instinto de conservación que impone su ley, pero que deja poco campo para hacer las cosas con cabeza. Ante el miedo funciona más el instinto que la razón.

La consecuencia o consecuencias más directas y perniciosas de esta forma de actuar fueron el aislamiento eclesial y la pérdida del tren de la historia.

9. ZAMBARBIERI, A., Los concilios del Vaticano. San Pablo, Madrid, 1995, pp. 76.

10. DZ. HERDER, Barcelona, 1963, N. 1780, pp. 413. 
La iglesia siguió viviendo encorchetada en su propio recinto, mientras el mundo o la cultura moderna seguían caminos totalmente distintos. El discurso eclesiástico no tenía eco en la sociedad. Tal situación, con sus altibajos, se prolonga hasta el dintel del concilio Vaticano II. La frase de Juan XXIII sobre la necesidad de abrir las ventanas de la iglesia, para que entrara en su recinto aire fresco y nuevo, se hace programática. El concilio Vaticano II dibuja otro rostro eclesial hasta el extremo de congraciarse con la cultura moderna. No voy a entrar ahora si este estado de cosas permanece presente en la iglesia de nuestro tiempo o si, por el contrario, se alzan por ahí voces y conductas de restauración y vuelta al pasado. De ser así, estaríamos de nuevo ante situaciones que el concilio Vaticano II había superado con creces.

Lo apuntado sería más que suficiente para intentar en el marco de la iglesia católico-romana la re-visión propuesta en el enunciado. Pero queda lo más profundo del tema. Y en ello me voy a entretener ahora. Es algo que salta a la vista, siempre y cuando se esté un poco en onda de los temas ecuménicos, que el Ministerio papal, su acuñación teológica y el tema de su infalibilidad constituyen piedra de escándalo para todas las otras iglesias. Lo grave del tema es que todas las iglesias sienten necesidad de un Ministerio de unidad. Esta necesidad se acusa con más fuerza en aquellas iglesias salidas de la Reforma que han padecido con más virulencia el drama de la desunión. Ello quiere decir que el Primado papal no se cuestiona por las iglesias, al menos por las iglesias más significativas. Ni siquiera por las iglesias ortodoxas que, en el tema, tienen una sensibilidad muy acusada. Todas ellas estarían dispuestas a aceptar dicho primado, si éste se presentara en términos más pastorales y menos jurídicos. En fórmulas teológicas que respondan a una exégesis estrictamente bíblica y a una eclesiología de comunión y trinitaria.

Para poder ofrecer un cuadro suficientemente representativo del tema, se impone la tarea de reproducir la enseñanza del concilio Vaticano I sobre el papado. "Ahora bien, lo que Cristo Señor, príncipe de los pastores y gran pastor de las ovejas, instituyó en el bienaventurado Apóstol Pedro para perpetua salud y bien perenne de la iglesia, menester es dure perpetuamente por obra del mismo Señor en la iglesia que, fundada sobre la piedra, tiene que permanecer firme hasta la consumación de los siglos. 'A nadie a la verdad es dudoso, antes bien, a todos los siglos es notorio que el santo y beatísimo Pedro, príncipe y cabeza de los Apóstoles, columna de la fe y fundamento de la iglesia católica, recibió las llaves del reino de manos de nuestro Señor Jesucristo, Salvador y Redentor del género humano; y, hasta el tiempo presente y siempre, sigue viviendo y preside y ejerce el juicio en sus sucesores' (Cf. Con. de Efeso, v. 112), los obispos de la Santa Sede Romana, por él fundada y por su sangre consagrada. De donde se sigue que quienquiera 
sucede a Pedro en esta cátedra, ése, según la institución de Cristo mismo, obtiene el primado de Pedro sobre la iglesia universal" ${ }^{11}$.

Establecido el hecho, viene luego la formulación teológica en los siguientes términos: "Enseñamos, por ende, y declaramos, que la iglesia Romana, por disposición del Señor, posee el principado de potestad ordinaria sobre todas las otras y que esta potestad de jurisdicción del Romano Pontífice, que es verdaderamente episcopal, es inmediata. A esta potestad están obligados por el deber de subordinación jerárquica y de verdadera obediencia los pastores y los fieles de cualquier rito y dignidad, ora cada uno separadamente, ora todos juntamente, no sólo en las materias que atañen a la fe y a las costumbres, sino también en lo que pertenece a la disciplina y régimen de la iglesia difundida por todo el orbe; de suerte que, guardada con el Romano Pontífice esta unidad tanto de comunión como de profesión de la misma fe, la iglesia de Cristo sea un solo rebaño bajo un solo pastor supremo. Tal es la doctrina de la verdad católica, de la que nadie puede desviarse sin menoscabo de su fe y salvación" 12 .

Culmina esta formulación conciliar sobre el Ministerio papal con un canon, que merece la pena transcribir. "Así, pues, si alguno dijere que el Romano Pontífice tiene sólo deber de inspección y dirección, pero no plena y suprema potestad de jurisdicción sobre la iglesia universal, no sólo en las materias que pertenecen a la fe y a las costumbres, sino también en las de régimen y disciplina de la iglesia difundida por todo el orbe, o que tiene la parte principal, pero no toda la plenitud de esta suprema potestad; o que esta potestad suya no es ordinaria e inmediata, tanto sobre todas y cada una de las iglesias, como sobre todos y cada uno de los pastores y de los fieles, sea anatema" 13 .

Así queda esculpida por el concilio Vaticano I la figura del Romano Pontífice. Quien escucha este mensaje, y lo hace desde una actitud de fe adulta, lo que significa no dejarse amedrentar por los contenidos expresados, no puede por menos de sentirse sorprendido. Aquí todo es sorprendente. Sorprende el inmediatismo con que se miran los textos bíblicos. La figura de Pedro pasa químicamente pura al Romano Pontífice. Y no sabe uno o, mejor, uno se da cuenta de que la figura del Pedro bíblico y su Ministerio son una proyección de la figura del Papa y del modo cómo se quiere ver el ejercicio de su Ministerio. El humilde pescador de Galilea, vestido de turbante, llevando humildes sandalias y una túnica de camino es ahora el Señor

11. IB. $\mathrm{N}^{\circ} .1824$, pp. 423.

12. IB. $N^{\circ} .1827$, pp. 424.

13. IB. No. 1831. pp. 425. 
coronado con la tiara, vestido de blanco, adornado de un poder absoluto y pleno, dominando a la heredad del Señor y no sirviendo a la misma.

Sorprende la facilidad con que el concilio Vaticano I descubre voluntades de Cristo, a la hora de organizar su iglesia. Todo viene determinado de forma directa, hasta el extremo que el Romano Pontífice es sin más ni más el sucesor de Pedro. Y ello por expresa voluntad de Cristo. Hasta se nos llega a decir que Pedro es el fundador de la iglesia romana. Cosa que la historia desmiente sin paliativos. Todo esto no parece responder más que a posturas dogmáticas y, desde luego, carece del suficiente fundamento histórico. Esta carencia histórica cuestiona muy seriamente las afirmaciones hechas por el concilio Vaticano I. Por lo que no extraña que, a pesar de la rotundidez de las mismas, haya muchos creyentes cristianos que no alcanzan a descubrir cosas que el concilio Vaticano I presenta de forma tan evidente. Y ello no hay que atribuirlo, ésta es siempre la salida fácil, a intenciones torcidas o a malas voluntades. La tendencia muy propia de instituciones religiosas a dar respuestas dogmáticas a problemas muy complicados deja al descubierto sus enormes lagunas y termina por crear posturas de rechazo.

El punto más grave del tema se halla en la eclesiología que hay de base en toda esta doctrina. No hay que agudizar mucho el entendimiento para darse cuenta que estamos ante una eclesiología de carácter universal y con fisonomía piramidal. La iglesia de Cristo es una realidad universal que sobrevuela a las iglesias particulares y, como tal, debe tener una cabeza visible. Dicha cabeza es el papa, cuya potestad es ordinaria e inmediata sobre toda la iglesia. El papa, tal y como aparece retratado por el concilio Vaticano I, es una especie de superobispo, que hace inviable la eclesiología local y anula la figura de los demás obispos. Para salir al paso de esa más que posible situación, el concilio Vaticano I afirma lo siguiente: "Ahora bien, tan lejos está esta potestad del Sumo Pontífice de dañar a aquella ordinaria e inmediata potestad de jurisdicción episcopal por la que los obispos que, puestos por el Espíritu Santo (cf. Hech 20,28), sucedieron a los Apóstoles, apacientan y rigen, como verdaderos pastores, cada uno la grey que le fue designada; que más bien esa misma es afirmada, robustecida y vindicada por el pastor supremo y universal, según aquello de San Gregorio: 'Mi honor es el honor de la iglesia universal. Mi honor es el sólido vigor de mis hermanos. Entonces soy yo verdaderamente honrado, cuando no se niega el honor que a cada uno es debido' ${ }^{14}$. Se trata, como puede detectarse con facilidad, de una declaración bien precisa. Pero una cosa es hacer una declaración y otra cosa es ser consecuentes. La doctrina conciliar sobre el Ministerio papal es

14. B. $N^{\circ} .1828$, pp. $424-425$. 
de tal envergadura que deja las manos libres al papa para el ejercicio de un Ministerio que anule en la práctica al de los obispos. Tenemos, incluso hoy y después del concilio Vaticano II, ejemplos abundantes. Ejemplos, por supuesto, negativos. Por citar uno muy significativo, ahí está el Sínodo de los obispos. Fue creado por Pablo VI como expresión de colegialidad. ¿Qué es de hecho? Un instrumento al servicio de la monarquía papal. El papa se reserva el nombramiento de un número alto de asistentes al mismo. Quienes acuden a su celebración no tienen voto deliberativo. Todo su trabajo pasa en secreto al papa. Y éste, tras una no pequeña dilación, que casi conlleva olvidar que se celebró un Sínodo de obispos que trató un tema concreto, publica una exhortación sinodal. Toda la mecánica del Sínodo está en contra de un ejercicio colegial del Ministerio episcopal. Y no se debe olvidar que esto está sucediendo tras la celebración de un concilio, el Vaticano II, que tuvo al menos la intención de fomentar la colegialidad entre los obispos. Por tanto, una cosa son las declaraciones oficiales y otras las realidades que se mueven en la vida. El concilio Vaticano I acuña una formulación del Ministerio papal con cara de monarquía religiosa que, por esta razón, es la que más inclinada está a convertirse en tiranía. Con una figura así huelga todo discurso que trate de ver a la iglesia como retrato de la Trinidad y como misterio de comunión.

Sin apenas darnos cuenta se ha llegado al centro del problema. Centro que se llama eclesiología. La solución correcta del problema del Ministerio depende del modelo de eclesiología que se ponga en marcha. Hay una eclesiología piramidal y verticalista, cuyo esquema representativo es: Cristo-la jerarquía-la iglesia como comunidad de fieles. Como se puede apreciar en el esquema transcrito la jerarquía se pone por delante de la comunidad y se alza como mediación indispensable entre Cristo y la comunidad. El Ministerio jerárquico queda aislado y viene a ser una instancia insoslayable para comunicar con la Cabeza. De este esquema afirma el siempre circunspecto P. Congar: "Tal esquema, aunque contenga una parte de verdad, presenta sus inconvenientes. En un primer tiempo, por lo menos, sitúa el sacerdocio ministerial como anterior, y exterior, a la comunidad. Tal como se puso en práctica, reducía de hecho la construcción de la comunidad a la acción del ministerio jerárquico. Ahora bien, la realidad pastoral y lo mismo el Nuevo Testamento imponen una perspectiva mucho más rica. Es Dios, es Cristo quien, por su Espíritu Santo, no cesa de construir la iglesia. Esta no es una mera institución jurídica asentada de una vez para siempre y que subsistiría por el simple juego de las estructuras de la institución, sin que el Señor haya de intervenir en ella continua y activamente. Lo cual no puede mantenerse, ni en consideración al actualismo de Dios, ni en relación con una necesaria 
pneumatología, ni ante el redescubrimiento de los carismas y de la verdad de los ministerios por los que Dios construye la iglesia" 18 .

El concilio Vaticano I usa el esquema eclesial antes reflejado. Esquema, por lo demás, que no sólo no se ajusta al implicado y complicado desarrollo de los ministerios tal y como aparecen en el Nuevo Testamento, sino que corre el riesgo de magnificar a los ministros en detrimento de la comunidad. Claramente es lo que acontece en el concilio Vaticano I. La figura papal, que este concilio dibuja, es de tal magnitud, es una figura tan barroca, que prácticamente anula a la realidad eclesial. Aunque sea un tanto exagerado, uno recibe la impresión de que el papa es la iglesia sin más. Eso, al menos, desde el sistema operativo. Quien marca el ritmo, quien dice lo que hay que hacer, designa lo que está bien o lo que está mal es el papa. Los demás miembros de la iglesia se reducen a ver las cosas de forma meramente pasiva. Tienen que esperar qué es lo que decide el papa. No extraña, por lo tanto, que un Pío $\mathrm{X}$, a principios del siglo XX, pueda escribir con la conciencia segura de que está dando en la diana: "En la sola jerarquía residen el derecho y la autoridad necesaria para promover y dirigir a todos los miembros hacia el fin de la sociedad. En cuanto a la multitud, no tiene otro derecho que el de dejarse conducir y, dócilmente, el de seguir a sus pastores" ${ }^{19}$. Es verdad que Pío X habla de la jerarquía. Pero la historia, siempre centinela de las cosas reales, nos dice que la jerarquía tiene un nombre: el papa. El papa, tal y como lo perfila el concilio Vaticano I, tiene en sus manos todos los medios para encarnar una monarquía religiosa. Una buena muestra de esta acuñación ministerial papal se halla en las palabras con que termina el párrafo que define la infalibilidad papal. "Y, por tanto, que las definiciones del Romano Pontífice son irreformables por sí mismas, y no por el consentimiento de la iglesia" ${ }^{20}$. La autarquía está servida en bandeja.

Si el modelo eclesial recordado tiene tan graves y crudos inconvenientes, no es ni siquiera justo con los datos históricos, está inficionado de un mal dogmatismo, la opción a tomar está bien clara. Hay que abandonarlo. Es lo que acontece tanto en ambientes ecuménicos, como en teólogos sensibilizados con las cuestiones ecuménicas. Cito, en primer lugar, al P. Congar, teólogo católico pionero en temas ecuménicos. "La entrada por la puerta y el concepto de la comunidad sería más satisfactoria. Huiríamos así de dos concepciones desafortunadas: igualmente desafortunadas, además. No sería el esquema lineal (Cristo-Sacerdocio-fieles), con el peligro de hacer del

15. CONGAR, Y., Ministerios y comunión eclesial. FAX, Madrid, 1973, pp. 18.

16. Ib., pp. 14.

17. DZ. N 1839 , pp. 424. 
Sacerdocio jerárquico una mediación que supondría un pueblo menor, impotente y pasivo. No sería una especie de democratismo que los Protestantes no profesan, aunque a veces algunas expresiones suyas podrían inquietar...; porque no hacen de los ministros puros delegados de la comunidad; sostienen que Dios ha querido y, en este sentido, instituido ministerios, pero de manera global, de suerte que no se puede deducir del Nuevo Testamento un tipo de organización que se le impusiera iure divino de forma absolutamente normativa. Son las iglesias las que, por su disciplina, organizan ministerios, teniendo en cuenta lo que la Escritura puede decir a ese propósito..." ${ }^{18}$.

E. Schillebeeckx apuntala el tema en cuestión de forma clara y brillante. "Los actuales ministerios eclesiales (episcopado, presbiterado y diaconado) no fueron instituidos directamente por Jesús. Los análisis históricos demuestran que ciertos modelos preexistentes en el mundo judío y helenístico, así como las exigencias de la situación histórica de la iglesia, han influido en la estructura concreta del gobierno de las comunidades. El proceso sociológico que desembocó dentro de la iglesia en el episcopado, presbiterado y diaconado, a partir de otros ministerios mucho más numerosos en su origen (de los que muchos desaparecieron o se reagruparon en otros), se interpreta legítimamente, por motivos eclesiológicos -la iglesia es, en efecto, el templo del Espíritu Santo- como la obra misma del Espíritu Santo, el Espíritu de Cristo glorificado. Así, pues, aunque su origen no se remonte a una institución por el Jesús histórico, esos ministerios son, en virtud del carácter pneumático de la iglesia estructurada Apostólicamente, el fruto del Espíritu y no el mero resultado de un proceso sociológico. En este sentido se puede afirmar que los ministerios eclesiales son de 'derecho divino'. Pero ese 'derecho divino' debe comprenderse de tal forma que suponga y haga posible un desarreglo histórico de las formas y de la distribución de las competencias ministeriales. Por tanto es posible que evolucionen las estructuras, no sólo en el pasado, como lo ha demostrado la historia, sino también en el futuro, al menos en la medida en que la iglesia puede reconocer en dicha evolución la acción del Espíritu Santo. Teniendo en cuenta lo que hay de único en el Apostolado, está claro que el gobierno Apostólico de la iglesia primitiva tiene que servir de modelo a la hora de buscar un criterio que permita reconocer el carácter pneumático de la reestructuración propuesta" ${ }^{19}$.

Las dos significativas citas nos ponen en el camino acertado. Como fácilmente se detecta, ellas nos ofrecen un modelo eclesiológico distinto al que hizo acto de presencia en el concilio Vaticano I y siguió estando presente

18. CONGAR, Y., Ministerios y comunión eclesial. FAX, Madrid, 1973, pp. 20.

19. SCHILLEBECKX, E., La misión de la iglesia. Sígueme, Salamanca, 1971, pp. 488-489. 
durante muchos años en la iglesia católico-romana. En este nuevo modelo entran dos factores de importancia única. Por una parte, el Espíritu Santo. Por otra, la comunidad. La presencia del Espíritu Santo conlleva una visión de la iglesia sometida al movimiento, al dinamismo. Por ser Espíritu sus actuaciones eclesiales están al servicio de la vida eclesial. Son vivas. Que es lo mismo que decir que se hallan en permanente movimiento de cambio. Lo importante para la iglesia es llevar a cabo la misión recibida. Fidelidad que pedirá constantes cambios de formas y estructuras. Ninguna de estas dos cosas puede tener carácter de intocabilidad. Sólo tienen razón de ser en tanto en cuanto ayudan a la iglesia a cumplir mejor la misión recibida. Cuanto más pneumatólogica sea, es decir, cuanto más se deje mover por el Espíritu, que no es otro que el Espíritu de Cristo, tanto más estará preparada para salir de y romper los encorchamientos estructurales. La fidelidad de la iglesia no se salva por el hecho de mantener una forma concreta de Ministerio. Se salva si el Ministerio que tiene sirve a la predicación del Evangelio, que es lo que justifica la realidad de la iglesia. El carnet de identidad para la iglesia no es un Ministerio concreto. El carnet de identidad para la iglesia es si predica o no el Evangelio del Señor. Las figuras actuales del Ministerio son producto de factores diversos y complejos. En otras circunstancias y en otros ambientes hubieran sido distintas. Lo que las justifica es si estas figuras ministeriales son aptas para cumplir la misión eclesial. Lutero que, aparte estridencias bruscas, tiene intuiciones teológicas geniales, dice acerca de los obispos, el Ministerio cumbre de muchas iglesias: "Si los obispos lo fuesen de verdad y se decidiesen a atender a la iglesia y al evangelio, por motivos de caridad y de unidad -pero no por una necesidad-se les podría permitir que ordenasen y nos confirmasen a nosotros y a nuestros predicadores, con tal de que prescindiesen de todas las apariencias y fantasmagorías de una pompa que nada tiene de cristiano. Pero no son obispos verdaderos ni desean serlo; mejor estaría decir que son señores y príncipes seculares, a quienes no interesa predicar, ni enseñar, ni bautizar, ni administrar la santa cena, ni ejercer obra ni ministerio de la iglesia; es más, persiguen y condenan a los que ejercen este ministerio por su vocación. Por eso, la iglesia no tiene que prescindir de sus ministros a causa de los obispos" ${ }^{20}$. Queda bien a las claras qué es lo que Lutero nos quiere transmitir. Está retratando una situación, la de su tiempo, que no es la que nosotros estamos viviendo. Pero su pensamiento de fondo es válido para siempre. Si los obispos no cumplen la misión para la que han sido llamados, sobran y no hay razón para mantener su ministerio. La simple presencia de obispos en una iglesia no es sin más argumento de que esa igle-

20. EGIDO, T., Obras de Lutero. Sígueme, Salamanca, 1977, pp. 355. 
sia sea iglesia de Jesucristo. Lo será, si ellos, como instrumentos, predican el auténtico Evangelio del Señor.

Sin apenas notarlo, se ha entrado en el terreno adecuado para entender teológicamente la razón del Ministerio, tenga la forma concreta que tenga. El Ministerio sólo se puede entender, si se sitúa en el tejido de la iglesia. La iglesia es la depositaria directa de todo lo que mira a la salvación de la humanidad. Esta afirmación es de capital importancia. Todas las afirmaciones, que en el evangelio aparecen dirigidas a los Doce, deben ser visionadas desde este ángulo de vista. Hans Küng se pregunta: “¿Quién sucede a los apóstoles?". Y responde:

'Esta misión divina que Cristo confiara a sus apóstoles durará hasta el fin del mundo (cf. Mt 28,20), puesto que el evangelio, que por su medio debía transmitirse, es en todo tiempo, para la iglesia, principio de toda vida' (CE 20). La Constitución pasa de esta tesis fundamental y general a la sucesión de los ministerios eclesiásticos.

La respuesta fundamental sólo puede ser una: la iglesia. No algunos particulares: la iglesia entera sucede a los apóstoles. ¡Confesamos la iglesia apostólica! En efecto, la iglesia entera es el nuevo pueblo de Dios congregado por los apóstoles por medio de la predicación del evangelio de Jesucristo" ${ }^{21}$.

Se entiende así que el Ministerio, cuya misión y razón de ser es servir a la salvación de los creyentes, no puede aislarse de la iglesia. El horizonte adecuado para comprender el Ministerio es el eclesial. Dicho de otra forma: si el Ministerio se aísla del ministerio de la iglesia, y esto es lo que ha sucedido en la eclesiología tradicional católico-romana, se termina en un tratado de jerarcología. Este punto de vista, es decir, situar el Ministerio en el ministerio, es decir, partir de la iglesia a la hora de hablar del Ministerio específico, es el adoptado por el ecumenismo. "La iglesia tiene, por consiguiente, la misión de proclamar el evangelio a todos, creyentes y no creyentes. Esta misión o servicio de toda la iglesia es llamada 'ministerio' (diakonía)... El ministerio de la iglesia, entendido de esta manera, se distinguirá del (o un) Ministerio, una forma particular de servicio -un orden específico, función o carismaque se encuentra dentro y en beneficio de la iglesia de Cristo en su misión hacia el mundo. El término Ministro empleado en este documento se refiere a la persona a quien ha sido confiado este Ministerio. Estamos convencidos de que el Ministerio especial no puede ser discutido aparte, sino en el contexto del ministerio de todo el pueblo de Dios"22. "El Ministerio ordenado

21. KÜNG, H., La iglesia. Herder, Barcelona, 1970, pp. 442-423.

22. GRUPO TEOLÓGICO LUTERANO-CATÓLICO DE ESTADOS UNIDOS. Eucaristía y ministerio. Seminarios 57-58, Vol. 21, 1975, №. 9, pp. 471. 
debe ser entendido como un elemento de la comunidad. Para comprender el Ministerio, es pues, necesario partir de la naturaleza de la iglesia, comunidad de creyentes. Es por esto por lo que las consideraciones que siguen tienen como punto de partida a la comunidad cristiana; después, intentan definir la naturaleza y las funciones del Ministerio ordenado a la luz de esta comunidad" 23 .

El P. Congar resume así el tema: "Habría, pues, que sustituir el esquema lineal por un esquema donde la comunidad apareciese como la realidad envolvente en cuyo interior los ministerios, incluso los ministerios instituidos o sacramentales, se situarían como servicios de eso mismo que la comunidad está llamada a ser y a realizar" 24.

La doctrina del concilio Vaticano I sobre el Ministerio papal se articula en base a una eclesiología piramidal, jerárquica, lineal. La comunidad aparece al final de la línea y siempre con el estigma de pasar por las horcas caudinas (perdón por la expresión un tanto fuerte, pero cargada de simbolismo), de un Ministerio que se construye teológicamente al margen de la comunidad. Y, como tal, tiene más características de poder que de servicio. La iglesia aparece, vistas así las cosas, identificada con los Ministros. El pueblo de Dios es simplemente una añadidura sin contenido y sin función. "Un pueblo menor, impotente y pasivo", nos decía el P. Congar en uno de los textos cita$\operatorname{dos} 25$.

En base a todo lo dicho, la doctrina del concilio Vaticano I sobre el Ministerio papal debe ser sometida a una profunda re-visión. Empresa que se presenta todavía más imperiosa, si se tiene en cuenta que dicha formulación acerca del Ministerio papal es piedra de escándalo para todas las demás iglesias y se alza como muro insalvable de separación con ellas. Una iglesia, es el caso de la iglesia católico-romana, que deplora la situación de divisón como una desobediencia a la voluntad del Señor, no puede quedar con las manos cruzadas. Debe comprometerse seriamente en la tarea y hacer los esfuerzos necesarios y a su alcance para que la unidad de los cristianos deje de ser algo sentimental y se traduzca en hechos concretos. Entre los temas insoslayables a reflexionar se halla el del Ministerio papal.

La tarea está dibujada. Pero surgen inmediatamente unas preguntas: ¿No se ha hecho ya? ¿Acaso no se ha celebrado un segundo concilio Vaticano que ha elaborado una hasta cierto punto nueva eclesiología? ¿Justo esa eclesiología de pueblo de Dios, en la que la comunidad antecede a los Ministros?

23. FE Y CONSTITUCIÓN. Documento de Accra. Seminarios 57-58. Sígueme, Salamanca, 1975, Vol. 21, No. 2, pp. 557.

24. CONGAR, Y., Ministerios y comunión eclesial. FAX, Madrid, 1973, pp. 21.

25. Ib. pp. 20. 
Así es, en efecto. Y hay que agradecer a este concilio el cambio eclesiológico realizado por él. Un cambio nada fácil, pues tuvo que hacerse tras largas y dolorosas renuencias a lo que la Comisión preparatoria había elaborado. Fruto de ese trabajo denso y hasta cierto punto arriesgado fue la Constitución sobre la iglesia, la Lumen Gentium (=LG).

Yo no voy a cantar aquí las bellezas teológicas, que las tiene a granel, de la Constitución sobre la iglesia. No entra en el horizonte de este artículo tal empresa, que, por cierto, me encanta. Yo estoy tratando de los retos ecuménicos que pesan sobre la iglesia católico-romana. Y, si pesan, es que están todavía sobre sus espaldas. No se han cumplido. Entre esos retos, y en obsequio a las demás iglesias, se halla la re-visión de su doctrina sobre el Ministerio papal. Doctrina que, como ya dije, se alza como piedra de escándalo de separación con las demás iglesias. Esta labor, a mi humilde modo de ver, no la llevó a cabo el concilio Vaticano II. Esto es lo que voy a intentar poner de relieve.

Como muy bien se puede ver, la Constitución sobre la iglesia dedica el capítulo III a hablar de los Ministros. Prácticamente, de los obipos, con unos reducidos números dedicados a los presbíteros y diáconos. El encabezamiento mismo ya suscita problemas. Se habla de La constitución jerárquica de la iglesia y en particular del episcopado. Supongo que el encabezamiento proviene del mismo concilio. Si se trata de un añadido, para indicar de qué se va a tratar a continuación, tal añadido está justificado siempre y cuando refleje lo que se va a decir. Por lo que, a la larga o a la corta, estamos ante el mismo fenómeno o ante el mismo contenido.

A mí no me gusta el título. Y no digo tal cosa por un afán tonto de hacerme notar. Lo digo, porque estoy plenamente convencido que dicho título es una desviación sustancial de lo que Jesús mandó acerca de la forma de comportarse quienes tuvieren la misión de servir a la comunidad. Veámoslo. De todos es sabido que la palabra griega arjé, de donde se deriva jerarquía, habla de poder. Con ello se nos quiere decir que la iglesia está organizada conforme a categorías de poder. Lo cual no parece muy en consonancia con lo que los evangelios nos dicen sobre el tema. "No ha de ser así entre vosotros, dice Jesús a sus discípulos; sino que el que quiera llegar a ser grande entre vosotros, será vuestro servidor, y el que quiera ser el primero entre vosotros, será esclavo de todos". (Mc 10,43-44; par. Mt 20,24-28; Lc 22,2427). Y añade: "Que tampoco el Hijo del hombre ha venido a ser servido, sino a servir y a dar su vida vida como rescate por muchos" (Mc 10,45).

A lo que hay que añadir que en ningún sitio del Nuevo Testamento se usa la palabra arjé, cuando se habla del ministerio. Para esta función se usa siempre la palabra diakonía, cuyo significado directo es, ni más, ni menos, 
servicio. Es cierto que Pablo habla (cf. 1 Cor 7,19; 2 Cor 10,8) de exousía, poder, que le viene de Cristo y al que él renuncia por el bien de los fieles. Pero está bien claro que tal poder no tiene nada de poder en el sentido propio de la palabra. Se trata simplemente de la capacidad de predicar el evangelio, capacidad que le autoriza para cumplir una misión recibida de arriba. La iglesia, por tanto, no puede tener una constitución jerárquica. La iglesia debe tener una constitución diakónica. Esto es lo que se deduce del Nuevo Testamento. Y esto es lo que hace de la iglesia una realidad única. Atractiva. Incomparable.

Los bienes, que se siguen de esta visión neotestamentaria del Ministerio, no se reducen a adjetivos admirativos, como los reseñados. Se traducen en profundas y sugestivas realidades. Al ver la iglesia como comunidad diacónica, quienes ejercen la diaconía no se alzan con categorías de superioridad sobre el resto de la comunidad. El Ministerio no es propiamente un estado creador de escalones dignatarios. No. Todos los miembros de la comunidad son radicalmente iguales. Lo que sucede es que unos ejercen unas funciones que otros no ejercen. Lo que da sentido a la función es el ejercicio de la misma. No el título. Esto cuestiona muy profundamente la praxis eclesial actual y revive aquella disposición del Concilio de Calcedonia que prohibía las órdenes absolutas. El obispo lo es tal, cuando tiene una comunidad a la que sirve. No hay épiscopé sin comunidad. A la luz de todo esto, no tiene justificación la praxis de nombrar obispos para ser secretarios de Congregaciones romanas o para representar al papa como Nuncios. Y así sucesivamente. Lo más importante de toda esta forma de ver el Ministerio es que se elimina de una vez por todas el peligro de crear diferencias o castas entre los miembros de la comunidad cristiana.

La visión del Ministerio en categorías de poder, expresión de la misma la palabra jerarquía, es la culpable de la presencia en una realidad salvífica del término jurisdicción. Es uno de los términos más cáusticos que uno puede imaginar. Su sola presencia ha hecho posible esa lucha por el poder existente entre obispos de diócesis especiales. Por lo que no extraña que tal palabra sea la piedra angular del edificio del primado papal. El papa tiene, así habla el primer concilio Vaticano, "plena y suprema potestad de jurisdicción sobre la iglesia universal" ${ }^{26}$. Los demás obispos, se entiende con facilidad, la tienen sólo participada y subordinada. En unión con el papa, como cabeza natural del episcopado, formando un colegio alcanzan también la plena y suprema potestad.

26. DZ. HERDER, Barcelona, 1963, Nº. 1821, pp. 425. 
Así están las cosas, incluso después del concilio Vaticano II. Por lo que todavía no se ha hecho re-visión del Ministerio papal, que yo proponía como tarea a la iglesia católico-romana. Voy a intentar mostrar, prefiero esta palabra a la palabra demostrar, para no dar la sensación de que estamos ante problemas matemáticos. En teología hay que andar siempre con mucha cautela y evitar absolutismos que suelen conducir siempre a callejones sin salida.

Apenas iniciado el tema sobre la constitución jerárquica de la iglesia, el concilio Vaticano II hace la siguiente declaración. "Para que el episcopado fuese uno e indiviso, estableció (Jesucristo) al frente de los demás apóstoles al bienaventurado Pedro, y puso en él el principio y fundamento, perpetuo y visible, de la unidad de fe y de comunión. Esta doctrina de la institución, perpetuidad, fuerza y razón de ser del sacro primado del Romano Pontífice y de su magisterio infalible, el santo Concilio la propone nuevamente como objeto firme de fe a todos los fieles y, prosiguiendo dentro de la misma línea, se propone, ante la faz de todos, profesar y declarar la doctrina acerca de los obispos, sucesores de los apóstoles, los cuales, junto con el sucesor de Pedro, Vicario de Cristo y cabeza visible de toda la iglesia, rigen la casa del Dios vivo" 27 .

Se cae de su peso que el concilio Vaticano II está hablando de la enseñanza del concilio Vaticano I acerca del primado del papa. Y nos dice, sin más y con fuerza inusitada, que tal enseñanza se propone de nuevo como objeto de fe firme a todos los fieles. La frase para un poco la circulación de la sangre. El asunto es de tal envergadura que a cualquiera se le para la respiración y siente sobre su cabeza la amenaza de la excumunión, si acaso se le ocurre cuestionar lo expresado. $\mathrm{Y}, \sin$ embargo, no parece que haya otra alternativa y que tal alternativa se impone en razón de una fe adulta. El concilio Vaticano II no puede despacharse con una salida como la que reflejan sus palabras. Y no puede hacerlo, si sus palabras, al principio del decrero sobre el ecumenismo, tienen alguna garantía de sinceridad. "Promover la restauración de la unidad entre todos los cristianos es uno de los fines principales que se ha propuesto el sacrosanto concilio Vaticano II" ${ }^{28}$. Un concilio de la categoría del Vaticano II tenía que saber a ciencia cierta que la formulación teológica que el concilio Vaticano I hizo del primado del papa era piedra de escándalo para muchas iglesias. En concreto, para las iglesias ortodoxas. Con esa formulación por delante es imposible ni siquiera soñar la unión con la ortodoxia. Se imponía la tarea de volver sobre las declaraciones del

27. $L G 18 \mathrm{~b}$.

28. UR 1 . 
concilio Vaticano I y situar el primado del papa en la eclesiología que el mismo concilio Vaticano II había alumbrado y de la que era su denfesor. El momento oportuno estaba servido. Pero el concilio Vaticano II se inhibe y se escuda en recordar lo que se había dicho. Con ello se hace un flaco servicio al ecumenismo.

Los males no quedan aquí. El concilio Vaticano II, tras marginar el tema del primado papal, manifiesta su intención de ofrecer una doctrina sobre los obispos. De esta doctrina sólo me voy a fijar en lo que mira a su relación y articulación con el Ministerio papal. El concilio Vaticano II habla de los obispos desde la colegialidad. Los obispos, junto y siempre con el papa, forman un colegio. Este colegio tiene sus raíces en el colegio de los apóstoles. Oigamos sus palabras: "Así como, por disposición del Señor, San Pedro y los demás apóstoles forman un solo colegio apostólico, de igual modo se unen entre sí el Romano Pontífice, sucesor de Pedro, y los obispos, sucesores de los apóstoles. Ya la más antigua disciplina, conforme a la cual los obispos establecidos por todo el mundo, comunicaban entre sí y con el obispo de Roma con el vínculo de la unidad, de la caridad y de la paz, como también los concilios convocados para resolver en común las cosas más importantes contrastándolas con el parecer de muchos, manifiestan la naturaleza y forma colegial propia del orden episcopal. Forma que claramente demuestran los concilios ecuménicos que a lo largo de los siglos se han celebrado... Uno es constituido miembro del colegio episcopal en virtud de la consagración sacramental y por la comunión jerárquica con la Cabeza y miembros del colegio.

El colegio o cuerpo episcopal, por su parte, no tiene autoridad, si no se considera incluido el Romano Pontífice, sucesor de Pedro, como cabeza del mismo, quedando siempre a salvo el poder primacial de éste, tanto sobre los pastores como sobre los fieles. Porque el Pontífice Romano tiene, en virtud de su cargo de Vicario de Cristo y Pastor de toda la iglesia, potestad plena, suprema y universal sobre la iglesia, que puede ejercer siempre libremente" ${ }^{32}$.

El texto citado daría suficiente materia para un artículo. Está lleno de imprecisiones en varias de sus afirmaciones. Por lo que respecta al tema de este artículo, quiero poner mis ojos en el tema de la colegialidad. Es un tema precioso. Decir colegialidad es decir participación, comunión. El collegium, que de ahí viene colegialidad, supone que sus miembros son colegas, es decir, que sus miembros gozan de una igualdad radical. San Cipriano, escribiendo a Esteban, obispo de Roma, le llama colega. Es un término totalmente acertado. Si todos los obispos, incluido el de Roma, forman un colegio, y

29. $L G 22 \mathrm{a}$ y b. 
así lo dice el concilio Vaticano II, ¿cómo puede incrustarse en un ente colegial una figura papal de la que se dice que tiene potestad plena, suprema y universal sobre la iglesia y que además puede ejercerla siempre libremente? Una figura papal, acuñada en términos tan jurídicos, términos de contenido de poder, poder, por lo demás, pleno, supremo y universal, revienta, y perdón por la palabra tan fuerte, la realidad de la colegialidad. En última instancia, quien tiene la voz de mando es el papa. Y la colegialidad consistirá en afirmar y confirmar lo que afirma y dice el papa.

$\mathrm{Si}$ acaso estas palabras resultan un tanto extrañas y hasta fuertes, quiero traer aquí un texto de un teólogo reformado, Jean Bocs, teólogo de una gran finura y delicadeza en su valoración de la Constitución sobre la iglesia. "La cuestión está en saber en qué medida un primado definido en términos tan rigurosos no contiene en germen la negación del ejercicio de la colegialidad. Si el papa tiene verdaderamente en la iglesia el poder pleno, supremo y universal, que puede ejercer siempre libremente, $i$ no será posible, por lo menos en principio, poner en duda la autoridad del concilio?; tanto más cuanto que el concilio habla del papa como de la cabeza visible de la iglesia o como de la cabeza de la iglesia visible. Pero, ¿no es colegial toda la estructura de la iglesia precisamente porque la comunidad cristiana no podría tener más cabeza que a Jesucristo mismo presente y operante allí donde dos o tres están reunidos en su nombre? Es importante darse cuenta de que no es el primado, en cuanto tal, lo que se pone en discusión en la doctrina de los reformados...

La dialéctica de los poderes del papa y del concilio, tal y como aparece en el texto de la constitución, es una dialéctica en ruptura de equilibrio y va en detrimento, a los ojos de las iglesias de la reforma, de un dato eclesiológico fundamental" 30 .

Jean Bocs, un teólogo reformado, ha realizado en las palabras transcritas un juicio sereno y objetivo. Un juicio que, aparte miedos dogmáticos, puede compartir cualquier teólogo católico. En efecto, es fácil descubrir la enorme tasa de incoherencia que se da en la doctrina católica en la tarea de intentar articular enseñanza sobre el Ministerio papal y colegialidad. Un obispo, en el caso el obispo de Roma, que tiene como individuo un poder pleno y supremo y luego participa del mismo poder, como cabeza del colegio episcopal, tiene todas las cartas a su favor para hacer de por sí y ante sí lo que crea necesario o conveniente. No hay nada que pueda obstaculizar su labor. Se dirá que tal cosa no sucederá nunca, dada la gran altura moral y mística de

30. BOCS, J., Puntos de vista de los teólogos protestantes sobre el Vaticano II. Madrid, 1969, pp. 30-31. 
su detector. Lo cual no es un salida muy afortunada. Aquí se trata de un problema teológico. No de idiosincrasias particulares. Que, por lo demás y la historia lo confirma, en el tema ha habido de todo. Basta que nos encontremos con un papa autoritario, que posea además una conciencia supersensible de su misión única, para encontrarse con situaciones anormales. Una buena muestra de que no estoy hablando de memoria se halla en la famosa nota que el secretario general del concilio Vaticano II, Pericles Felici, impuso al final del capítulo III como clave de lectura para lo que se había dicho sobre la colegialidad. Nota que se hizo con conocimiento y aprobación de Pablo VI. "El Sumo Pontífice, como Pastor supremo de la iglesia, puede ejercer libremente su potestad en todo tiempo, como lo exige su propio Ministerio" 33 . Como se ve, el tema no deja lugar a dudas.

Siendo el Ministerio papal el punto más conflictivo por lo que mira a la unión con la Ortodoxia, es imposible marginar aquí alguna referencia a estas iglesias, que tienen al Patriarca Ecuménico de Constantinopla como su representante más cualificado. Hay que decir sin vacilación que la acuñación doctrinal que hace del Ministerio papal la iglesia católico-romana nunca será aceptada por este grupo de iglesias. Por tanto, el camino de la unidad está obstruido, siempre y cuando la iglesia católico-romana no re-formule su doctrina sobre el Ministerio papal. Oigamos un texto significativo por un doble aspecto. En primer lugar, por la persona que lo pronuncia. Se trata del ya fallecido Dimitrios I, sucesor del Patriarca Atenágoras, tan recordado en el tema. En segundo lugar, por el momento en que hace sus afirmaciones. Es en la homilía que pronuncia en su toma de posesión, a cuyo acontecimiento acudió una delegación vaticana. "Hablando de nuestras iglesias nosotros no desistimos de la doctrina eclesiológica sobre la iglesia una, santa, católica, apostólica; nosotros entendemos, de este modo, a las iglesias locales, respetadas cada una en su jurisdicción... Estamos obligados a repetir y a señalar aún una vez más que en la cristiandad ningún obispo posee ningún privilegio, divino o humano, sobre la iglesia una, santa, católica y apostólica de Cristo, sino que todos nosotros, sea en Roma, sea en esta villa de Constantinopla, sea en cualquier otra villa -cualquiera que sea su posición en la jerarquía eclesiástica o en el mundo político- ejercemos nuestra carga episcopal en la colegialidad pura y simple, bajo un solo pontífice supremo, que es la cabeza de la iglesia, nuestro Señor Jesucristo, y ello según el orden jerárquico aceptado desde siempre en la iglesia" ${ }^{32}$.

31. Ib. pp. 112.

32. TIMIADIS, E., El primado de Pedro y eclesiología ortodoxa. Istina, 4(1978), pp. 363. 
Una simple comparación del texto escrito por Dimitrios I y la doctrina sobre el Ministerio papal acuñada por la iglesia católico-romana deja bien a las claras las diferencias sustanciales de ambas posturas. Dimitrios deja ver con facilidad cuál es su concepción eclesial. Se trata de una eclesiología local. Unida inseparablemente a una eclesiología eucarística. Y, como reflejo de la Trinidad, una eclesiología trinitaria. En todo este marco eclesial no encaja una figura papal, tal y como la presenta la doctrina católico-romana. Y, por lo mismo, el camino de la unidad con las iglesias ortodoxas sigue cortado, sin posibilidad de dar un paso efectivo hacia adelante. Habrá encuentros, declaraciones, gestos. No es poco. Pero la unión entre ambas iglesias no se dará.

De ahí el título de este apartado. Llamativo, si se quiere, pero necesario también, si se quiere trabajar con eficacia en la unión de las iglesias cristianas. El reto, que estaba ahí, no lo asumió Juan Pablo II. Por eso, la carta encíclica no contiene nada nuevo. Incluso hasta me parece que Juan Pablo II, veladamente, por cierto, pero con suficiente claridad, vuelve al modelo de ecumenismo llamado unionista. "La iglesia católica, tanto en su praxis como en sus documentos oficiales, sostiene que la comunión de las iglesias particulares con la iglesia de Roma, y de sus obispos con el obispo de Roma, es un requisito esencial -en el designio de Dios- para la comunión plena y visible. En efecto, es necesario que la plena comunión, que encuentra en la eucaristía su suprema manifetación sacramental, tenga su expresión visible en un Ministerio en el cual todos los obispos se sientan unidos en Cristo y todos los fieles encuentren la confirmación de la propia fe" ${ }^{33}$.

El texto no deja lugar a dudas. Juan Pablo II dice, y lo dice claramente, que la unión de las iglesias pasa por la comunión de las iglesias particulares con la iglesia de Roma y de sus obispos con el obispo de Roma. Y añade: esto "es un requisito esencial -en el designio de Dios- para la comunión plena y visible". Sin tal comunión con Roma y con su obispo no es posible alcanzar la plena y visible comunión. La carga de esta empresa pesa sobre las espaldas de las otras iglesias, mientras que la de Roma aparece como el centro hacia el que tienen que converger todas las otras. A lo que hay que añadir que todo ello se presenta como designio divino. Es voluntad de Dios, clara y tajante, que ello acontezca tal y como lo presenta Juan Pablo II. Como se ve, Juan Pablo II deja las cosas tal y como estaban. Y hasta da la impresión de resucitar un modelo de ecumenismo que parece había quedado enterrado definitivamente. Con estos presupuestos ideológicos, la unión con las demás iglesias no parece tener una presencia cercana.

33. JUAN PABLO II, Ut unum sint. 97a. 


\section{SEGUND0 RET0: EN UNIÓN CON TODAS LAS IGLESIAS QUE HAN HECHO DEL EPISCOPADO SU MINISTERIO CENTRAL Y EN OBSE- QUIO A LAS IGLESIAS QUE HAN PRESCINDIDO DEL EPISCOPADO, UNA MEJOR TEOLOGÍA BÍBLICA DEL MINISTERIO}

La Reforma es un acontecimiento eclesial de primera magnitud. Con ella se da en la iglesia la segunda gran división. Las iglesias, que surgieron como consecuencia del movimiento luterano y otros movimientos en línea parecida, se apartaron de la iglesia católico-romana. En verdad que una tal situación no entraba en la mente de Lutero y demás seguidores suyos. El, y ellos, perseguían llevar a cabo una reforma eclesial que hiciera honor a la consigna dada ya por el concilio de Constanza. Con el tiempo las cosas se fueron agravando. Y llegó un momento en que la separación impuso su ley. Nacieron así las iglesias de la Reforma, que poseen diferencias doctrinales importantes con la iglesia católico-romana.

En atención al horizonte de este artículo, yo me voy a fijar solamente en lo que respecta al Ministerio especial. Casi todas las iglesias salidas de la Reforma prescindieron de la figura del obispo. Tal decisión, a primera vista intrascendente, resulta compleja y comprometida, a la larga. Y ello es así, porque el episcopado se había presentado como canalizador de la sucesión apostólica. Sólo la iglesia que pudiera presentar una lista de obispos que conectaran con los apóstoles podría considerarse apostólica. Y, por lo mismo, podría considerarse como iglesia de Jesucristo ${ }^{34}$.

Se entiende fácilmente que aquí nace un problema de gran envergadura. Las iglesias, que han colocado en el episcopado el eje de su apostolicidad, no pueden aceptar la apostolicidad de aquellas iglesias que han prescindido del episcopado. A su vez, las iglesias, que han prescindido del episcopado, no aceptan que se las cuestione su condición de ser verdaderas iglesias de Jesuscristo. Una tal situación exige un esfuerzo de investigación, con el fin de ver si hay un camino que pueda conducir a la solución del problema.

El problema sube de tensión, si se tiene en cuenta que, al romper la sucesión apostólica, se rompe también la validez de los sacramentos. En concreto, y por las incidencias del mismo en la vida cristiana, la validez del sacramento de la eucaristía. Este nuevo dato añade entidad a la tarea de buscar algún camino que pueda llevar a ver las cosas de forma distinta. Y así lograr superar el muro, a primera vista infranqueable, de la separación.

Tal camino parece que existe. Y por él han intentado caminar los movimientos ecuménicos y abrir así una puerta a la esperanza. Quien se adentra

34. Cf. $L G 18$ b. 
por este camino tiene que poner los ojos en lo que la Escritura del Nuevo Testamento dice acerca de la organización ministerial. Las iglesias, de las que habla el Nuevo Testamento, no tienen una forma uniforme de organizarse. Lo cual deja bien a las claras que en este tema no vale acudir a una voluntad expresa del Señor para imponer un modelo de Ministerio. Hay en el tema libertad y creatividad.

Por tipificar un poco el tema, fijemos la atención en algunas iglesias concretas. La iglesia-madre de Jerusalén se organiza, dado el entorno en que nace, siguiendo un modelo judío. Ella aparece dirigida por Santiago, el hermano del Señor, acompañado de un colegio de ancianos. Se trata, como fácilmente se puede descubrir, de un Ministerio de dirección colegiada. Hay, eso sí, una especie de jefe, Santiago, pero el ejercicio de la misma es colegial. El hecho es una buena cura, a la hora de flexibilizar lo que actualmente se dice en algunas iglesias sobre el episcopado. Santiago no es un obispo al estilo moderno de la palabra. Y, sin embargo, dirige una iglesia de características muy peculiares. Es la iglesia-madre. La iglesia que hace posible el nacimiento de otras iglesias. Sin la comunidad de Jerusalén no hubiera surgido el movimiento cristiano y las futuras iglesias. Aparte de la función de dirección, nada se sabe de otras funciones de Santiago y su colegio de ancianos.

A renglón seguido, toca hablar de la iglesia de Antioquía o en Antioquía. Esta iglesia nace como consecuencia de la dispersión subsiguiente a la muerte de Esteban. Se trata de una iglesia excepcional por su importancia. Antioquía se convierte muy pronto en el centro misionero cristiano más importante de la antigüedad. Pues bien, esta iglesia está dirigida por profetas y maestros. Dos Ministerios relacionados con la enseñanza y no tanto con la dirección. Dos Ministerios que, según un lenguaje de entonces, son carismáticos cien por cien.

De Antioquía salen Bernabé y Saulo para llevar a cabo su primer viaje apostólico. Se debe a una intervención misteriosa del Espíritu. Oigamos el texto: "Mientras estaban celebrando el culto del Señor y ayunando, dijo el Espíritu Santo: 'Separadme ya a Bernabé y a Saulo para la obra a la que los he llamado'. Entonces, después de haber ayunado, les impusieron las manos y les enviaron" (Hech 13, 2-3).

Merece la pena resaltar algunos datos. Bernabé y Saulo son enviados. Y son enviados por una iglesia, que va a alcanzar la categoría de iglesia-madre para las iglesias que Bernabé y Saulo funden durante su viaje. En señal de comunión con la iglesia enviante se les imponen las manos. Es un simple gesto de comunión. No es un signo sacramental. Bernabé y Saulo son apóstoles en estricto sentido de la palabra. Apóstol significa enviado. Parece ser que es en Antioquía en donde se acuña este calificativo que luego va a tener 
una importancia única. Naturalmente que el término apóstol no es unívoco. Tiene distintas significaciones. Lo que hace que el tema de la apostolicidad se desbloquee y se constituya en una buena vía de acercamiento entre las iglesias. Los enviados, al término de la misión, se vuelven a su punto de partida. Y, para dejar bien claro que no han obrado por su cuenta, sino como enviados, reúnen a la iglesia y dan cuenta de su viaje Es una consecuencia normal del gesto de la imposición de manos, cuyo significado no es otro que el de la comunión. Lo importante de todo este mensaje cara a una visión más flexible del Ministerio episcopal es que la iglesia de Antioquía está dirigida por ministros de carácter estrictamente carismático.

La iglesia de Corinto, fundada por Pablo, es la que mejor conocemos en base a los datos que nos da el Nuevo Testamento. Seguramente es la iglesia en donde la comunidad tiene un papel más relevante. Si hay un problema, Pablo no dice que se reúnan los dirigentes y junto con la comunidad deliberen sobre su solución. "Reunidos vosotros y mi espíritu, les dice en el caso del incestuoso, con el poder de Jesús Señor nuestro, sea entregado ese individuo a Satanás para destrucción de la carne, a fin de que su espíritu se salve en el Día del Señor" (1 Cor 5, 4b-5). En Corinto no hay obispos, ni ancianos. Hay, en verdad, dirigentes, pues nunca la iglesia es una comunidad ácrata. En primer lugar está Pablo, como fundador de la iglesia, como padre que quiere vivir en una relación de amor más que de poder. "Pues aunque hayáis tenido diez mil pedagogos en Cristo, no habéis tenido muchos padres. He sido yo quien, por el Evangelio, os engendré en Cristo Jesús" (1 Cor 4,15). Están también cristianos que, asentados en Corinto, se han puesto al servicio de los hermanos y hermanas. Pablo nombra a la familia de Estéfanas, primicia de Acaya. Pide para ella sumisión y también para todos aquellos y aquellas que con ella trabajan y se afanan (cf. 1 Cor 16, 15ss).

En Filipos, iglesia fundada por Pablo, aparecen muy pronto los episcopos y diáconos. En el saludo de la carta, Pablo se presenta de la siguiente forma: "Pablo, Timoteo, siervos de Cristo Jesús, a todos los santos en Cristo Jesús, con los epíscopos y diáconos. Gracias a vosotros y paz de parte de Dios nuestro Padre y del señor Jesucristo" (Flp 1,1-2).

Se podía seguir aduciendo datos sobre el tema, datos ofrecidos por el Nuevo Testamento, y ofrecer un cuadro más amplio de la evolución que sufre todo lo referente al Ministerio en el Nuevo Testamento. A medida que la iglesia se va estabilizando y va perdiendo su fervor misionero, cosa normal en cualquier institución, los Ministerios de dirección imponen su ley. Es así como se llega a la figura del obispo monárquico. El obispo concentra en su persona funciones que no tuvo el epíscopo-presbítero, que aparece en la segunda generación cristiana y del que tenemos un retrato moral en las car- 
tas Pastorales. Predica, administra los sacramentos, en especial la eucaristía, rige al pueblo de Dios. Su figura se magnifica hasta el extremo de aparecer como un semidiós. Muchas de las expresiones presentes en las cartas de Ignacio de Antioquía van en esta línea. "En Asia Menor es donde mejor se puede seguir la génesis del ministerio episcopal. Las cartas de San Ignacio de Antioquía ya contienen el dicho: 'Quien se opone a él (al obispo), se opone a Dios'; 'donde está el obispo está la comunidad, lo mismo que donde está Cristo está la iglesia católica'. Por estas cartas y la de san Policarpo sabemos que hacia finales del siglo primero ya se habían separado los ministerios del obispo y del sacerdote; el primer nombre se reservó para el jefe de la comunidad: el obispo. Los presbíteros se convirtieron en sus auxiliares. Vemos ya un orden jerárquico que culmina en el obispo (imagen del padre), por encima del presbítero y de los diáconos" 35 .

Los datos reseñados tienen la suficiente densidad como para hacer algunas afirmaciones importantes. Hay en el tema del Ministerio creatividad y evolución. Lo que pone de manifiesto que la comunidad cristiana no recibe de Jesús ningún mandato al respecto. De haber existido tal mandato, se hubiera reflejado en la historia. Por tanto, no es una buena política religiosa acudir a voluntad o voluntades de Jesús para justificar la presencia de un Ministerio determinado. Lo que no me parece que se da en algunos documentos del magisterio católico y otros documentos de iglesias que tienen al obispo como su ministro fundamental. "Enseña, pues, este sagrado Sínodo que los obispos han sucedido por institución divina en el lugar de los apóstoles como pastores de la iglesia y quien a ellos escucha, a Cristo escucha, y quien los desprecia, a Cristo desprecia y al que le envió (cf. Lc 10,16)" ${ }^{36}$. Hay en el texto una expresión que llama profundamente la atención. Por institución divina. ¿Qué quiere expresar? ¿Se quiere decir con ella que los obispos suceden a los apóstoles, porque así lo determinó el mismo Jesús? Si este es el mensaje, hay que decir que se comete aquí un anacronismo. Que es lo mismo que afirmar que la expresión no responde a la realidad. ¿Se quiere afirmar que la aparición del Ministerio episcopal, al ser realidad eclesial, no es un simple hecho sociológico, aunque la sociología tenga mucho que ver, sino que en ello interviene el Espíritu Santo como fuente que es de la vida de la iglesia? No habría nada que oponer a tal interpretación. Así piensa, y me parece estar en lo cierto, un teólogo tan brillante como es E. Schillebeeckx. "Los actuales ministerios eclesiales (episcopado, presbiterado, diaconado) no fueron instituidos directamente por Jesús. Los análisis históricos

35. LORTZ, J., Historia de la iglesia. I. Ed. Cristiandad, Madrid, 1982, pp. 134.

36. $L G 20$ b. 
demuestran que ciertos modelos preexistentes en el mundo judío y helenístico, así como las exigencias de la situación histórica de la iglesia, han influido en la estructura concreta del gobierno de las comunidades. El proceso sociológico que desembocó dentro de la iglesia en el episcopado, presbiterado y diaconado, a partir de otros ministerios mucho más númerosos en su origen (de los que muchos desaparecieron o se reagruparon con otros), se interpreta legítimamente, por motivos eclesiológicos -la iglesia es, en efecto, el templo del Espíritu Santo-, como la obra misma del Epíritu Santo, el espíritu de Cristo glorificado. Así, pues, aunque su origen no se remonte a una institución por el Jesús histórico, esos ministerios son, en virtud del carácter pneumático de la iglesia estructrurada Apostólicamente, el fruto del Espíritu y no el mero resultado de un proceso sociológico" 37.

A la luz de esta forma de ver la aparición de los Ministerios eclesiales es posible ya sacar algunas consecuencias que ayuden a ver los Ministerios de las iglesias que han prescindido del episcopado con ojos nuevos. El episcopado es un Ministerio importante en la vida de la iglesia. Y así lo reconocen las iglesias que no lo tienen, hasta el extremo de aceptar como una condición previa para la unión su restablecimiento. "La importancia del episcopado histórico no es disminuida por los descubrimientos arriba mencionados. Por el contario, esta nueva comprensión ha permitido a las iglesias, que no habían conservado el episcopado histórico, apreciarlo como un signo de la continuidad y de la unidad de la iglesia. Cada vez un mayor número de iglesias, que comprende a las que participan en las negociaciones para la unión, se declaran dispuestas a ver en el episcopado un signo preeminente de la sucesión apostólica de toda la iglesia en la fe, la vida y la doctrina; este hecho lo consideran como una realidad a la hay que tender en el caso en que no existiera. La única cosa que consideran incompatible con la investigación histórica y teológica contemporánea es la idea según la cual la sucesión episcopal sería idéntica a la apostolicidad de toda la iglesia y la contendría" ${ }^{38}$.

El documento de Accra, al que pertenecen los párrafos anteriores, tiene todas las calidades como para considerarle modélico. Responde a la historia y responde a una buena y correcta teología del Ministerio episcopal. Resalta por una parte su importancia. Pone de relieve el deseo de las iglesias que no lo tienen. Deseo que se traduce en una actitud de recuperarlo. Pero también deja bien claro cuáles son sus limitaciones. La sucesión episcopal no puede agotar todo el contenido de la apostolicidad de la iglesia. Se dibuja así un

37. SCHILLEBECKX, E., La misión de la iglesia. Sígueme, Salamanca, 1971, pp.488,

38. FE Y CONSTITUCIÓN. Documento de Accra. Seminarios 57-58, Sígueme, Salamanca, 1975, Vol. 21, No. 27, pp. 564-565. 
nuevo horizonte eclesiológico en el que hay que visualizar el valor y el significado del Ministerio episcopal. Estamos en una eclesiología de comunidad y no en una jerarcología. El Ministerio especial, en este caso episcopal, sólo es inteligible en el marco del ministerio eclesial. El concilio Vaticano II adoptó esta postura, aunque no la llevó a sus últimas consecuencias, cuando antepuso el capítulo II al III en la Constitución sobre la Iglesia. La depositaria del mensaje, de la transmisión del mismo, de la misión es la iglesia entera. La iglesia, y así se confiesa en el credo, es apostólica. El Ministerio está al servicio de la misión de la iglesia. Y sólo cuando cumple la misión es realmente lo que tiene que ser.

Lo importante en el tema es el cumplimiento de la misión. Lo secundario son las figuras ministeriales. Si una iglesia cumple la misión para la que existe está en la sucesión apostólica, aunque literalmente no tenga la figura episcopal. Para cumplir dicha misión tiene que tener figuras ministeriales. De ahí que el Ministerio, como tal, pertenece al ser de la iglesia. Las figuras concretas, no. Entendemos que el documento de Accra nos diga: "La única cosa que consideran incompatible con la investigación histórica y teológica contemporánea es la idea según la cual la sucesión apostólica sería idéntica a la apostolicidad de toda la iglesia y la contendría".

En base a estas investigaciones no resulta ya llamativo que iglesias, que han prescindido del episcopado, y, por lo mismo, a primera vista roto la línea de la sucesión apostólica, confiesen públicamente que están en posesión de un Ministerio válido. Los luteranos del Grupo teológico luterano-católico de estados Unidos afirman sin rubor: "Los luteranos abordan las cuestiones tratadas en esta declaración conjunta apoyándose en la convicción de que sus iglesias pertenecen a la iglesia una, santa, católica y apostólica. Ellos consideran sus ministros ordenados como personas válidamente segregadas para el Ministerio del evangelio y de los sacramentos en la iglesia de Cristo. Afirman que los sacramentos administrados entre ellos por estos ministros ordenados son sacramentos válidos. Los luteranos sostienen que en sus escritos confesionales permanecen en la auténtica tradición católica" ${ }^{39}$.

Schillebeeckx pone su guinda teológica al tema de forma brillante. "La validez del Ministerio, esto es, su autenticidad cristiana y eclesial, se determinan a partir de su función en la comunidad fiel a la iglesia apostólica, y en primer lugar a partir de la fides ecclesiae, la fe apostólica. Este principio no atañe solamente a la validez del bautismo, sino también a la del Ministerio. De aquí se derivan importantes consecuencias ecuménicas para la iglesia católica, por

39. GRUPO TEOLÓGICO LUTERANO-CATÓLICO DE ESTADOS UNIDOS. Eucaristía y ministerio. Seminarios 57-58. Vol. 21. Sígueme, salamanca, 1975, No. 23, pp. 476. 
el hecho de que el Vaticano II ha reconocido, en cierta medida, el carácter apostólico, y por tanto eclesial, de otras comunidades cristianas. Entonces, y en esta misma medida, se admite implícitamente la validez del Ministerio de dichas iglesias. El que la estructura eclesial se haya organizado de forma diferente en una parte y en otra después de la ruptura, esto no cambia para nada el problema. Prescindiendo de la colegialidad universal y del ministerio de Pedro (que puede desempeñar realmente un papel en otras estructuras eclesiales), no se puede considerar a las estruturas 'episcopales' o 'presbiterianas' como si fueran de suyo un factor dogmático de división en la iglesia. Como tales no suponen un obstáculo para la unidad, sino que son solamente otras maneras de organizar la iglesia, dogmáticamente legítimas" ${ }^{40}$.

En otra de sus obras afirma: "No estoy en contra de las institiciones de la iglesia: Pero son instituciones humanas, históricas, que deben evolucionar para el bien de los cristianos. Esto se ve por las cartas post-paulinas. Las instituciones se fundamentan en el hecho de que existe la iglesia, pero la institución como tal es una institución humana. Por ejemplo, no se puede decir que los obispos, los presbíteros, los diáconos, han sido instituidos por Jesucristo. Son fruto de una evolución. El episcopado, el sacerdocio y el diaconado, tal como son hoy, los tenemos desde la segunda mitad del siglo segundo. Son el fruto de una evolución lícita y positiva, pero no veo por qué no pueden cambiar.

En los documentos del Vaticano II -lo había ya señalado el concilio de Trento- ya no se dice que son una institución de Cristo. El concilio de Trento decía por disposición divina, es decir, han evolucionado históricamente por la acción de Dios. Trento corrigió la expresión por institución divina, prefiriendo la expresión por disposición divina. El Vaticano II eligió una tercera expresión: $a b$ antiquo, es decir, desde la antigüedad, porque, de hecho, la articulación jerárquica de la iglesia evolucionó siguiendo leyes sociológicas. Se da, sin duda, la vinculación con el Cristo histórico. El gran exegeta Descamps sostiene que los Doce tienen una conexión con Cristo. La iglesia es el nuevo Israel. En la comunidad de los Doce existe el ministerio petrino. Es un dato neotestamentario en cuanto la dirección de la iglesia pertenece a los Doce. Pero, ¿cómo puede ser ejercido el ministerio petrino? ¿Puede ser, por ejemplo, un triunvirato? ¿O un colegio? ¿O un Sínodo? Es una cuestión histórica, sujeta a cambios" ${ }^{41}$.

40. SCHILLEBECKX, E., La misión de la iglesia. Sígueme, Salamanca, 1971, pp. 494-495.

41. SCHILLEBECKX., E., Soy un teólogo feliz. Atenas, Madrid, 1994, pp. 111-112. 
Lo últimamente recordado lleva sin violencia a sacar algunas consecuencias, que ayuden a desbloquear ecuménicamente los problemas que pueden surgir por la ausencia en algunas iglesias de la figura del obispo. Me parece, y ello no supone ninguna claudicación en el ser eclesial, que lo importante en el tema no es tanto la figura ministerial, cuanto la misión. Diría con otras palabras: lo importante no es el episkopo, sino la episkopé. Esta es la tarea que pesa sobre la iglesia. Tarea que se especifica en predicar el evangelio, santificar por los sacramentos al pueblo de Dios y presidirlo evangélicamente. Para ello se necesita ministros, enviados por el Señor, pero a través de la iglesia, que obren tanto en el nombre de uno, como en el de la otra. El nombre concreto del ministro es absolutamente accidental. Lo que da entidad a la persona es la misión que realiza. En el caso, la episkopé. Que en una iglesia se llame obispo, en otra presbítero, en otra pastor es del todo irrelevante.

Se abre así una gran puerta para valorar el Ministerio de las distintas iglesias. La iglesia que, a través de sus figuras ministeriales, cumpla la episkopé estará dentro de la iglesia una, santa, católica y apostólica. La iglesia que no la cumpla, por más que tenga nominalmente obispos, no estará en el marco antes dibujado. Hay que fijarse bien en las afirmaciones. No se trata simplemente de deficiencias, que pueden darse en algunas iglesias y en algunos momentos y que afecten un tanto a la razón de su ser como enviada. Se trata de alejarse de su razón de ser, de no cumplir la misión que ha recibido. Y que ello, de alguna manera, afecte a tal iglesia de una forma un tanto permanente. Forma, por lo demás, que puede superarse por una auténtica conversión. Es decir, una iglesia, que vuelve a cumplir la episkopé marginada, entra de nuevo en la dinámica de la iglesia de Cristo.

Esta nueva visión de la importancia, por una parte, del Ministerio episcopal, y, por otra, de su relativización conlleva también una nueva visión de su valor en el tema de la sucesión apostólica. Dicha sucesión apostólica se presentaba casi siempre como una cadena ininterrumpida de obispos que conectaban con los apóstoles. Cuando esta cadena se rompía, y ello acontecía o bien por ordenaciones inválidas, o bien por falta de obispos, desaparecía, por el mismo hecho, la sucesión apostólica. Dicha iglesia dejaba de ser apostólica, que es lo mismo que afirmar que dejaba de ser iglesia de Cristo.

Hoy esta visión parece insostenible. Ello obedece tanto a una mejor y más amplia investigación de los Ministerios en el Nuevo Testamento y en los orígines de la iglesia, cuanto a un mejor enfoque de la eclesiología. Ninguna figura ministerial queda consagrada en el Nuevo Testamento. Si las cosas sucedieron como sucedieron fue efecto de muchos factores que no tienen un carácter inmediato de voluntad de Cristo. La cosa pudo evolucionar de otra forma perfectamente legítima. Según esto, canalizar la sucesión apóstolica a 
través de una figura ministerial, en el caso la de los obispos, es un reduccionismo teológico.

Si a ello añadimos la nueva comprensión de la iglesia, que no es otra que la de verla como el nuevo pueblo de Dios, el tema todavía se refuerza. El sujeto directo y próximo de todo lo que mira a la razón del ser de la iglesia es la misma iglesia. La iglesia viene a ser así, como ya se afirma sin rubor, el proto-sacramento de la salvación. Ella es la que debe llevar el evangelio hasta el extremo del orbe. Ella es la que tiene que santificar, en particular por la administración de los sacramentos, a todos los fieles. Ella es la que tiene la misión de apacentar y dirigir. Y ella es la sucesora y prolongadora de la misión apostólica. "Los apóstoles murieron; no hay nuevos apóstoles, pero la misión apostólica permanece. La misión de los apóstoles va más allá de la persona de los apóstoles. La misión apostólica no se recibe ya inmediatamente del Señor, sino que se realiza por medio de los hombres. Y en razón de la misión apostólica permanente, permanece el servicio apostólico. Pero este servicio apostólico no se cumple en cuanto alguien es llamado nuevamente al apostolado, sino por obediencia a los apóstoles como testigos y heraldos primigenios del Señor. Por razón, pues, de la misión permanente, hay en el servicio apostólico una sucesión apostólica, una sucesión apostólica en la obediencia. Intencionadamente no hablamos de apostolica succesio. Los problemas teológicos no deben obnubilarse con ideas secundarias, jurídicas y sociológicas. Nuestra pregunta, en cambio, es: ¿Quién sucede a los apóstoles?...

La respuesta fundamental sólo puede ser una: la iglesia. No algunos particulares; la iglesia entera sucede a los apóstoles. ¡Confesamos la iglesia apostólica! En efecto, la iglesia entera es el nuevo pueblo de Dios, congregado por los apóstoles por medio de la predicación del evangelio de Jesucristo. La iglesia entera es el templo del Espíritu, construido sobre el fundamento de los apóstoles. La iglesia entera es el cuerpo de Cristo que se mantiene unido por el ministerio de los apóstoles. Así, pues, la misión con plenos poderes de los apóstoles ha pasado a aquella iglesia que los apóstoles congregaron; el ministerio con plenos poderes de los apóstoles ha pasado a aquella iglesia a la que sirvieron los apóstoles, la iglesia es, en la obediencia, la sucesora de los apóstoles. Y por esta obediencia tiene ella poder y autoridad" 42.

42. KÜNG, H., La iglesia. Herder, Barcelona, 1970, pp. 423-424. 
Visualizada e interpretada de la forma reseñada la sucesión apóstolica, se consigue superar una de las mayores dificultades a la hora de caminar por el sendero del ecumenismo. Es la dificultad que se origina desde la perspectiva de la sucesión apostólica. La sucesión apostólica se veía normalmente desde el Ministerio. En concreto, desde el Ministerio episcopal. Sólo las iglesias que tenían un Ministerio episcopal válido podían ser consideradas como iglesia de Cristo. Con lo que muchas de las iglesias existentes, por carecer del Ministerio episcopal, no podían ser consideradas iglesias de Cristo. Cosa, por lo demás, rechazado por las mismas. Al considerar a la iglesia como tal sucesora de los apóstoles, tal dificultad desaparece. Y desaparece, porque entonces el Ministerio (uso la palabra con mayúscula para indicar que me refiero al Ministerio especial) queda englobado en el ministerio general de la iglesia. Los ministros no son, vistas así las cosas, autócratas, independientes. Son ministros en la iglesia y para la iglesia. La sucesión ministerial se enrola en la sucesión ministerial de toda la iglesia, hasta el extremo que recibe de ella su fuerza y su valor. Merece la pena recordar ahora cómo ve la sucesión apostólica uno de los documentos más representativos en el ámbito ecuménico. Me refiero al documento de Lima, elaborado por el FE Y CONSTIUCION. Dice: "La manifestación básica de los Apóstoles hay que encontrarla en la tradición apostólica de la iglesia en su conjunto. La sucesión es una expresión de la permanencia y, por consiguiente, de la continuidad del propio ministerio de Cristo, del que la iglesia participa. Dentro de la iglesia, el ministerio ordenado ejerce la tarea peculiar de preservar y actualizar la fe apostólica. La transmisión institucional del ministerio ordenado es, por tanto, una expresión eficaz de la continuidad de la iglesia a través de la historia; subraya asimismo la vocación del ministerio ordenado como guardián de la fe. Allí donde las iglesias consideran de poca importancia esta transmisión institucional, habrían de preguntarse si no tendrían que cambiar la concepción que tienen acerca de la continuidad en la tradición apostólica. Por otro lado, allí en donde el ministerio ordenado no presta un servicio adecuado a la proclamación de la fe apostólica, las iglesias tendrán que preguntarse por la necesidad de una reforma de sus estructuras ministeriales.

Bajo las especiales circunstancias históricas de crecimiento de la iglesia en los primeros siglos, la sucesión de los obispos fue una de las formas, junto a la transmisión del Evangelio y la vida de la comunidad, por las que se expresó la tradición apostólica de la iglesia. Esta sucesión se extendió como un servicio, un símbolo y una defensa de la continuidad de la fe y comunión apostólicas" ${ }^{43}$.

43. FE Y CONSTITUCIÓN. Documento de Lima. En Enchiridium Oecumenicum, 1986, Nrs. 35 y 36 , pp. 925 . 
Como se puede ver con facilidad, la investigación ecuménica ha conseguido tener una visión más justa del valor de la sucesión episcopal. Es una de las formas. No es, por lo mismo, la única forma de sucesión apostólica. Y, además, queda enmarcada dentro de la sucesión englobante de la iglesia. Con lo que se pone de relieve que el Ministerio, cualquiera que sea su forma concreta, no puede perder nunca de vista que es un Ministerio en la iglesia y para la iglesia. Si a todo esto se une ahora que todas las iglesias, al menos las más significativas, creen que la recuperación del episcopado por aquellas iglesias que lo han abandonado es una legítima y deseada aspiración cara la unión de las iglesias, entonces se da un verdadero fondo común que facilita enormemente la unión. El Ministerio, que ha constituido siempre piedra de escándalo a la hora de alcanzar la meta de la unión, deja de serlo. Con ello se supera un obstáculo de gran envergadura en la carrera hacia la meta de la unidad.

\section{TERCER RETO: EN UNIÓN CON TODAS LAS IGLESIAS, PROMOVER LA CELEBRACIÓN DE UN CONCILIO ECUMÉNICO SOBRE LA UNI- DAD}

Estoy convencido y confieso sin agobios que la unión de las iglesias cristianas es una gracia del Espíritu. Y las gracias se suplican. También estoy convencido y lo confieso sin traumas que la unión de las iglesias pide a los cristianos una verdadera conversión. Su vida debe ajustarse al evangelio. Debe seguir los pasos del Señor Jesús y poner su máxima aspiración en cumplir la voluntad del Padre.

Sin olvidar nada de esto, toca ahora poner manos a la obra. Es preciso que las iglesias se tomen el tema con seriedad y busquen con entereza y valentía andar los caminos de la unidad. Sobran en el tema sentimentalismos tontos. Y sobran, sobre todo, seudoapoyos dogmáticos. Hay que reconocer que la desunión de las iglesias es la carga negativa más grande que pesa sobre las espaldas de las iglesias. La voluntad del Señor al respecto está bien clara. En la oración, que el evangelista autor del evangelio de Juan, pone en labios de Jesús, el Señor deja bien definido cuál es su deseo. "Padre... que todos sean uno. Como tú, Padre, en mí y yo en ti. Que ellos también sean uno en nosotros, para que el mundo crea que tú me has enviado" (Jn 17, 1c.-21).

Las palabras son, como se puede ver, de una seriedad fuera de serie. Ellas nos advierten del mal, grave por cierto, que acarrea la desunión. No es otro que hipotecar la credebilidad del envío de Jesús por el Padre. Y ciertamente no hay que quitar virulencia al tema. La división de las iglesias consti- 
tuye el mayor inconveniente a la hora de aceptar el mensaje que intenta transmitir. Y es normal el asunto. Cualquiera que tenga un mínimum de inteligencia nota la incoherencia. Hablando todas en el nombre de Jesús, resulta que unas dicen cosas distintas de las otras. Y no sólo dicen cosas distintas, sino que imponen obligaciones diversas. Lo que agrava la cosa.

El absurdo alcanza cotas imposible de superar, cuando en el Credo se confiesa la iglesia como una. Es, como se puede comprender con facilidad, un momento de extraordinaria importancia. La iglesia se define como comunidad creyente y hace uso de una serie de formulaciones a través de las cuales configura su rostro de creyente. Pues bien, cualquier persona con sensibilidad se da cuenta que está confesando una cosa que no existe en realidad. Confiesa que la iglesia es una y se encuentra con una iglesia dividida. Es verdad que hay muchas cosas que apoyan dicha unidad. Pero también hay otras que están hablando de lo contrario. La unidad no es perfecta. Y, al no serlo, corrompe en gran escala la unidad. Todos sabemos que, fruto de esta situación, los creyentes en Jesús se niegan la comunión eucarística, que es el signo más sublime de la unidad. Basta para ello que formen parte de distintas iglesias. Y lo hacen, lo que todavía agrava más el tema, obligados por unas leyes que vienen de arriba. ¡Es una situación deplorable en cantidades inimaginables!

$\mathrm{Al}$ encontrarnos con consecuencias tan graves para el ser y la misión de la iglesia, cualquier esfuerzo para superar tal situación de división será pequeño, si tiene como meta alcanzar la unidad de las iglesias. En tal perspectiva se sitúa el concilio ecuménico sobre la unidad. Dicho concilio, como fácilmente se entiende, debe ser impulsado por quienes ejercen un Ministerio relevante de dirección en las iglesias. En la iglesia católico-romana, por el papa. En las iglesias ortodoxas, dependientes del patriarcado de Constantinopla, por el patriarca ecuménico. Y así sucesivamente.

Por tratarse de un concilio de tales características, deberá ser precedido por un largo período de preparación. Período en el que se estudien las cuestiones que apoyan la desunión y se busque una solución que responda correctamente al mensaje apostólico. Este mensaje, tal y como se halla recogido y transmitido en el Nuevo Testamento, será el espejo en el que todas las iglesias deben mirarse. Seguramente aparecerán cosas que, durante mucho tiempo y por algunas iglesias, se consideraron con carácter teológico y ahora se ven como un desarrollo histórico y, por lo mismo, con posibilidad de abandonarlas, sin que ello suponga para las iglesias pérdida de identidad.

Afortunadamente el movimiento ecuménico ha realizado ya una gran andadura, hasta el extremo que muchas cuestiones consideradas en tiempos pasados como motivo de desunión, hoy ya no tienen tal carácter. En temas, 
por ejemplo, como el Ministerio se ha llegado a conclusiones que hace unos años parecían cuentos de hadas. Hay quienes piensan que en este tema en concreto ya no hay motivo para mantener la desunión. "Dado que para el reconocimiento de los ministerios no existe ya ningún impedimento teológico decisivo, se ha superado un obstáculo importante para la plena comunidad en la Cena del Señor. Allí donde se dé una fe común en la presencia de Jesús en la Eucaristía es posible una mutua admisión a la santa Cena" ${ }^{44}$. También se han conseguido avances muy sustanciosos, casi definitivos, en el tema de la fe en la eucaristía. El Grupo ecuménico de Dombes, que es, por el elenco de sus miembros, uno de los más representativos, ha elaborado un documento sobre la eucaristía, que puede ser aceptado por cualquier iglesia cristiana. Todos sabemos que uno de los puntos claves en el tema es el modo como se quiere explicar la presencia del Señor bajo los signos. En la iglesia católico-romana, al amparo de un modelo filosófico muy concreto, la presencia del Señor bajo los signos se ha calificado de transustanciación. La sustancia de pan se convierte en la sustancia del cuerpo del Señor. La sustancia de vino, en la sangre del Señor. En otras iglesias, siempre sobre el presupuesto de la confesión en la presencia del Señor, se ha usado otro lenguaje y otra forma de ver dicha presencia. Me refiero principalmente a las iglesias salidas de la Reforma. Pues bien, el Grupo de Dombes ha elaborado un documento sobre la eucaristía que se puede considerar como aceptable por todos los creyentes. Dice sobre la presencia del Señor: "La acción eucarística es don de la persona de Cristo. En efecto, dice el Señor: 'Tomad y comed, esto es mi Cuerpo entregado por vosotros'. 'Bebed todos de él, porque esto es mi sangre, la Sangre de la Alianza derramada por la multitud en remisión de los pecados'. Confesamos, pues, unánimemente la presencia real, viva y activa de Cristo en este sacramento" 45 .

Como se puede ver, en base a los ejemplos recordados, el movimiento ecuménico ha conseguido metas importantes, al tiempo que ha limpiado de obstáculos en otro tiempo insalvables el camino de la unión. Todo esto debe ser recogido en la etapa preparatoria del concilio ecuménico.

Llegada la hora de celebrar el concilio ecuménico, todas las iglesias deben tener una representación suficientemente significativa, hasta el extremo de poder verse la magna asamblea como un verdadero concilio ecuménico. El instrumento por antonomasia de trabajo debe ser el diálogo. Partien-

44. INSTITUTOS ECUMÉNICOS ALEMANES. Reforma y reconocimiento de los ministerios. Seminarios 57-58. Vol. 21, Nº. 23. Sígueme, Salamanca, 1975, pp. 553.

45. GRUPO DE DOMBES. Acuerdo doctrinal sobre la eucaristía. En Enchiridium Aecumenicum. Salamanca, 1986, pp. 655. 
do de que ninguna iglesia debe sentirse superior a otra, $\mathrm{y}$ todas sometidas al juicio de la palabra de Dios y al impulso del Espíritu Santo, se examinarían las cuestiones debatidas en clima de comunión y conversión.

La comunión es un valor eclesial de primer orden. Nos habla de la relación íntima que existe entre todos los cristianos, que han sido sujetos de la presencia del Espíritu Santo, al recibir el bautismo. No se trata, por tanto, de relaciones exteriores, como se puede pensar, cuando se habla de palabras, gestos, actitudes que muestran una gran sensibilidad humana. Se trata del ser más profundo de la vocación cristiana. El Espíritu Santo, es, por su misma naturaleza, vínculo de caridad. Por lo que todos los miembros de las iglesias se deben sentir como verdaderos hermanos. Ya no sirve la denominacion que se daba en nuestra iglesia católico-romana de hermanos separados. La palabra "separados" es insultante y rompe la relación fraternal. Al sentir en sus personas la presencia del Espíritu Santo, como fuente inagotable de caridad, no resulta nada aventurado que las cosas a dialogar se vean con otros ojos. Actitud que hará descubrir con facilidad la rectitud de intención de todos los que se confiesan cristianos y ven en el Señor Jesús el fundamento de su fe. Todas las iglesias se preocupan por ser fieles al Señor. Por lo que las diferencias, a la hora de expresar dicha fidelidad, no pueden seguir en pie como muros de separación. Es indudable que la comunión, nacida de y alimentada por la presencia del Espíritu Santo, pone al alcance de la mano los medios para derribar los muros de separación.

La conversión debe ser la otra actitud que acompañe a las iglesias en el momento de celebrar el concilio ecuménico. Es evidente que en el tema nadie tiene las manos limpias. La separación se produjo bajo el signo del pecado eclesial. Por lo que la conversión, que supone el reconocimiento de las debilidades de las iglesias, debe ponerse como apoyo insustutuible para hacer que el diálogo produzca los frutos deseados. Bajo la mirada del Señor, todas las iglesias reconocerán su parte de pecado y pedirán el riego saludable de la gracia del Señor.

Todo ello reafirmará una convicción que ya corre por esos mundos de Dios. Es mucho más lo que une a las iglesias que lo que las separa. Incluso lo que las separa con frecuencia tiene poco peso teológico. Seguramente que se está ante la situación única de relativizar posturas, posturas que no pocas veces se han teñido de un falso dogmatismo, para lograr alcanzar la meta de la unidad. Es el momento de recordar algunos párrafos del concilio Vaticano II. Refiriéndose a las iglesias ortodoxas afirma. "Para el restablecimiento y mantenimiento de la comunión y de la unidad es preciso 'no imponer ninguna otra carga que la necesaria' (Hech 15,28)" "46. Fijándose ahora en las

46. UR $\mathrm{N}^{\circ} .18$. 
iglesias salidas de la Reforma, dice: "Nuestra atención se dirige, ante todo, a los cristianos que reconocen públicamente a Jesucristo como Dios y Señor y Mediador único entre Dios y los hombres, para gloria del único Dios, Padre, Hijo y Espíritu Santo... Movidos por el deseo de la unión con Cristo se ven impulsados a buscar más y más la unidad y también a dar tesimonio de su fe delante de todo el mundo" ${ }^{47}$.

Como se puede ver con facilidad, el núcleo de una misma fe queda bien claro en las diversas iglesias que aquí se mencionan. Frente a ese núcleo todo lo demás queda un tanto disminuido y no tiene por qué alzarse de forma insuperable como muro de separación. Alrededor de ese núcleo puede edificarse el edificio de una unidad que elimine el estigma de la desunión y ofrezca la garantía suficiente de que todos los que aman a Cristo, como su Dios y su Señor, no buscan otra meta que darlo a conocer así al mundo.

El final feliz de ese concilio ecuménico, compuesto por todas las iglesias de Cristo, tiene que ser, por necesidad vital, la celebración de una eucaristía comunitaria. La negación de la comunión eucarística ha sido el signo negativo de la falta de comunión. Las iglesias separadas se niegan mutuamente la comunión. Es una triste realidad. Por lo que debe desaparecer. Para ello no queda otra alternativa que optar por la celebración de una eucaristía en común, en donde las iglesias se den la mano, dándose la comunión. Este hecho es la mejor rúbrica de una unión que todas las iglesias buscan, y seguramente la buscan con sinceridad, pero que su presencia sigue sin llegar.

El concilio Vaticano II inicia el decreto sobre el ecumenismo con estas sugestivas palabras: "Promover la restauración de la unidad entre todos los cristianos es uno de los fines principales que se ha propuesto el sacrosanto concilio Vaticano II, puesto que única es la iglesia fundada por Cristo el Señor, aun cuando son muchas las comuniones cristianas que se presentan a los hombres como la herencia de Jesucristo. Los discípulos del Señor piensan de diverso modo y siguen distintos caminos, como si Cristo mismo estuviera dividido (cf. 1 Cor 1,13). División que abiertamente repugna a la voluntad de Cristo y es piedra de escándalo para la causa de la difusión del evangelio por todo el mundo" ${ }^{48}$.

No dudo que este clima ecuménico permanece vivo en la iglesia católicoromana. La fecha del año 2000, fecha paradigmática para todo el que cree en Cristo, es una buena referencia para avivar el espíritu ecuménico. Juan Pablo II así lo ha visto y fruto de ello ha sido la carta-encíclica Ut unum sint. La intuición ha sido buena. Pero la oferta ecuménica de Juan Pablo II queda

47. UR $\mathrm{N}^{\circ} .20$.

48. UR $\mathrm{N}^{\circ} .1$. 
absolutamente corta. Sobre la iglesia que Juan Pablo II preside, pesan retos ecuménicos que no se pueden marginar. Yo he recogido aquí, entre otros, el más crudo desde el punto de vista del Ministerio. Se trata del propio Ministerio papal. Estoy plenamente convencido que, mientras la iglesia católicoromana no lleve a cabo una nueva formulación teológica del Ministerio papal, la unión con las demás iglesias, en particular con las iglesias ortodoxas, no tendrá lugar.

Hasta ahora la iglesia católico-romana no ha asumido dicho reto. Más aun, tengo la impresión que el ejercicio de tal Ministerio en la iglesia actual católico-romana está endureciendo la configuración de un Ministerio que siempre ha tenido una formulación teológica de carácter piramidal. Al formular tal juicio de valor, no lo hago en base a un sentimiento que se llama espíritu antirromano. No. Lo hago sencillamente, porque creo que existen suficientes razones para formular tal afirmación. La primera parte de este estudio las ha dejado bien patentes. No hay por qué insistir en el tema.

Sobre la iglesia católico-romana pesan retos importantes a la hora de trabajar por la unión de las iglesias. Dados su significado e importancia dentro del cristianismo, debe aceptarlos con audacia, con parresia, para usar un término bíblico, cargado de contenido pneumatológico. No bastan al respecto los sentimentalismos, las lamentaciones. Es preciso revisar aquellas cuestiones que están levantadas como muros de separación. Revisarlas en diálogo. $\mathrm{Y}$, entre ellas, ocupa lugar de privilegio el Ministerio papal.

El camino a seguir no resulta demasiado arriesgado, siempre y cuando se superen excesivos celos dogmáticos. Se cuenta en el tema con la acogida favorable de todas las iglesias, que valoran positivamente la presencia en sus tejidos de un Ministerio de la unidad. No se cuestiona, por lo mismo el Ministerio papal como tal. Se custiona su acuñación dogmática. Aquí tiene la iglesia católico-romana que dar el do de pecho. ¿Es pedir mucho? No. "El diálogo ecuménico sobre el papado comporta... una invitación a la propia iglesia católica a que examine con franqueza y creativamente, de qué manera dicho ministerio puede realmente favorecer el camino hacia la unidad y prestar un humilde servicio al restablecimiento de la comunión entre las iglesias todavía separadas" 49.

Como posible horizonte esperanzador, siempre que se superen excesivos celos dogmáticos, traigo aquí unas palabras de Juan Pablo II. "Tarea ingente (se refiere a las formas con las que su Ministerio pueda realizar un servicio de fe y de amor reconocido por unos y otros), que no podemos rechazar y

49. VERCRUYSSE, J. E., Introducción a la teología ecuménica. Verbo Divino, Estella (Navarra), 1993, pp. 128. 
que no puedo llevar a término solo. La comunión real, aunque imperfecta, que existe entre todos nosotros, ¿no podría llevar a los responsables eclesiales y a sus teólogos a establecer conmigo y sobre esta cuestión un diálogo fraterno, paciente, en el que podríamos escucharnos más allá de estériles polémicas, teniendo presente sólo la voluntad de Cristo para su iglesia, dejándonos impactar por su grito "que ellos también sean uno en nosotros, para que el mundo crea que tú me has enviado'? (Jñ 17,21)" ${ }^{50}$.

¡Diálogo fraterno y paciente! ¡Teniendo sólo en cuenta la voluntad de Cristo para su iglesia! Las palabras de Juan Pablo II son una buena oferta y un buen camino a seguir. Pero ellas quedarán simplemente en eso, si, como representante primero de la iglesia católico-romana, se niega a re-visar lo que esta iglesia ha dicho sobre el Ministerio que él encarna y sobre la forma con que lo está ejerciendo.

Benito Dominguez SANCHEZ, OSA Estudio Teológico Agustiniano Valladolid 